Trakya Eğitim Dergisi

Cilt 9, Sayı 3

Eylül 2019, 506-526

Gelis Tarihi: 17.12.2018

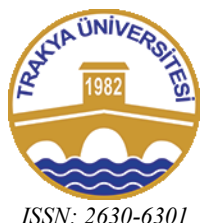

ISSN: 2630-6301
Trakya Journal of Education

Volume 9, Issue 3

September 2019, 506-526

\title{
Öğretmenlerin Kendini Sabote Etme Düzeyi ile Algıladıkları Örgütsel Destek Düzeyi Arasındaki İlișki ${ }^{1}$
}

\author{
The Relationship between Teachers' Level of Self-Handicapping and Perceived \\ Organizational Support Level
}

\section{Zeynep Meral TANRIÖĞGEN², Gülsüm SERTEL ${ }^{3}$}

\begin{abstract}
Öz: Ö̆gretmenlerin kendini sabote etme düzeyleri ile algıladıkları örgütsel destek düzeyi arasındaki ilişkiyi belirlemek amacıyla yapılan çalışmada, nicel araştırma yöntemlerinden ilişkisel tarama modeli kullanılmıştır. Çalışmanın örneklemini Denizli'de görev yapan 218 öğretmen oluşturmuştur. Çalışmada Jones ve Rhodewalt (1982) tarafından geliştirilen, Akın-Abacı ve Akın (2010) tarafindan Türkçe'ye uyarlanan "Kendini Sabotaj Ölçeği” ile Derinbay (2011) tarafindan geliştirilen "Algılanan Örgütsel Destek Ölçeği" kullanılmıştır. Araştırma sonucunda, öğretmenlerin kendini sabote etme düzeylerinin cinsiyet, medeni durum, eğitim durumu, yaş, okul türü, kıdem, kurumdaki hizmet süresi, branş değişkenlerine göre anlamlı bir farklılık oluşturmadığ görülmüştür. Katılımcı öğretmenlerin kendini sabote etme düzeyi ile öğretimsel destek alt boyutu negatif yönde orta düzeyde; adalet alt boyutu ile negatif yönde düşük düzeyde ilişkili olduğu görülmüştür.
\end{abstract}

Anahtar sözcükler: Kendini sabotaj, Algılanan örgütsel destek

\begin{abstract}
In order to determine the relationship between selfhandicapping levels of teachers and the level of organizational support perceived, relational survey model of quantitative research methods is used. The sample of the study consisted of 218 teachers working in Denizli. In the study, "Self Sabotage Scale" which was developed by Jones and Rhodewalt (1982) and adapted to Turkish by Akın-Abacı and Akın (2010) and "Perceived Organizational Support Scale" developed by Derinbay (2011) were used. As a result of the research, it has been found that teachers' selfhandicapping levels did not differ significantly according to gender, educational status, age, type of school,. It has been found that the level of self-handicapping and the instructional support sub-dimension of the participant teachers were negatively related at a moderate level; there was a low level of negative relationship with the justice sub-dimension.
\end{abstract}

Keywords: Self-handicapping, Perceived organizational support

\section{Introduction}

\section{EXTENDED ABSTRACT}

The study was aimed to determine the relationship between self-handicapping levels and the level of organizational support as perceived by teachers. In the field of educational administration and organizational behavior, perceived organizational support has an important role in terms of reflecting the mutual relations between the employees and the administration. The perception of organizational support also contributes to the development of positive attitudes towards the organization at the individual and organizational level, the reduction of negative psychology and negative organizational behavior. Teachers need to have higher performance in order for gaining the skills of 21 st century, keeping up with the pace of changing and evolving information, increasing the expectations for success in education and training services. It is thought that this research will contribute to administrators, researchers and literature in order to better understand the sabotaging behaviors of teachers who postpone their work in schools or who take shelter behind excuses, who have avoided taking part in tasks and who display attitudes and behaviors to restrain their performance consciously.

Conscious and deliberate self-sabotage behavior harms the individual, his work and the organization in which he works. Therefore, this situation, which has a disruptive attitude and behavior, leads to a decrease in the quality of teaching and learning activities and to a decrease in effectiveness and efficiency in the school. In this context, it is seen as an important necessity to examine the factors that cause teachers to

\footnotetext{
${ }^{1}$ Makale, 13-15 Eylül 2018 tarihleri arasında Aydın Adnan Menderes Üniversitesi Davutlar Meslek Yüksekokulu'nda düzenlenen II. Uluslararası Eğitim Araştırmaları ve Öğretmen Eğitimi Kongresi'nde (2ndEducation Research and Teacher Education Congress / ERTE Congress) sözlü bildiri olarak sunulmuştur.

${ }^{2}$ Dr. Öğr. Üys., Pamukkale Üniversitesi, Eğitim Fakültesi, Eğitim Bilimleri Bölümü, email: zmtanriogen@pau.edu.tr. ORCID:

${ }^{3}$ Öğretmen, Milli Eğitim Bakanlığı, email: gulsum_sertel@hotmail.com, ORCID:
} 
sabotage the teachers who are expected to be role models in educational institutions. In this study, the five following questions were asked to determine the relationship between the self-handicapping levels of teachers and the level of organizational support they perceived:

1. What is the level of self-handicapping behavior of teachers?

2. What is the level of organizational support that teachers perceive?

3. Does Teachers' self-sabotage level differ according to their (a) gender, (b) age, c) marital status, (d) educational status, (e) branches, (f) school type, (g) seniority, (h) service duration in school?

4. Is there a significant relationship between the level of self-sabotaging of teachers and the level of organizational support they perceive?

5. Is the level of organizational support perceived by the teachers a significant predictor of the selfsabotage level of teachers?

\section{Method}

In order to determine the relationship between self-handicapping levels of teachers and the level of organizational support perceived, relational survey model of quantitative research methods is used. A relational survey model was used in the research. The sample of the study included 134 (61.5\%) women and $84(38.5 \%)$ women in the province of Denizli who were working for basic training (primary, secondary) and high schools by simple random sampling from probability-based sampling methods. So, the sample was composed of 218 teachers totally. In this study two instruments were used to collect the data needed: (1) 'Self Sabotage Scale "which was developed by Jones and Rhodewalt (1982) and adapted to Turkish by Akın-Abacı and Akın (2010) and (2) "Perceived Organizational Support Scale" developed by Derinbay (2011). SPSS 22.0 package program was used in order to analyse the data, and as the data were found normally distributed, by using parametric tests. The regression analysis was performed with descriptive and correlational tests.

\section{Findings}

As a result of the research, it was observed that the levels of self-handicapping teachers' selfsabotage level were "partially agree" $(=2.78)$ and their perceived organizational support levels were "agree" (=3.83). It was determined that teachers' self-handicapping levels did not differ significantly according to gender, marital status, educational status, age, type of school, seniority, length of service in the institution and branch variables. It was concluded that teachers' self-handicapping level was negatively correlated with instructional support subscale $(r=-.325, \mathrm{p}<.01)$ and self - sabotage decreased with increasing instructional support dimension. By increasing the support of teachers in instructional issues, their self-sabotage tendencies can be reduced. Motivating activities that will reveal the performances of the teachers and provide opportunities for success, development and progress can be organized and self-efficacy levels can be increased. In order to prevent self-sabotage, teachers can be given professional support and their anxiety levels can be reduced and their self-esteem can be strengthened. Teachers can be empowered by cognitively and behaviorally. There is a low negative correlation between the self-handicapping level of the participant teachers and the justice sub-dimension $(\mathrm{r}=-, 160 ; \mathrm{p}<.05)$. It was found that there was a negatively low level of relationship $(\mathrm{r}=-, 243 ; \mathrm{p}<.05)$ between the self-handicapping level and the level of organizational support perceived by the participant teachers. The level of self-handicapping and the instructional support sub-dimension of the participant teachers were negatively at a moderate level; It was found that there was a low level of negative relationship with the justice sub-dimension.

\section{Result and Discussion}

As a result of the research, it has been found that teachers' self-handicapping levels did not differ significantly according to gender, marital status, educational status, age, type of school, seniority, service duration in the institution, branch and number of awards. It has been found that the level of selfhandicapping and the instructional support sub-dimension of the participant teachers were negatively related at a moderate level; there was a low level of negative relationship with the justice sub-dimension.

\section{GÍRIŞ}

Eğitim yönetimi ve örgütsel davranış alanında örgütte çalışanlar ile yönetim arasındaki karşılıklı ilişkilerin yansımaları açısından algılanan örgütsel destek önemli bir yere sahiptir. Örgütsel destek algısı, 
astların örgüte yönelik olumlu değerler geliştirmesine, negatif psikoloji ve olumsuz örgütsel davranışların azaltılmasına da katkıda bulunmaktadır. 21 yy. becerilerinin öğrencilere kazandırılması, değişen ve gelişen bilginin hızına ayak uydurmak, eğitim ve öğretim hizmetlerinde başarıya ilişkin beklentilerin artması, öğretmenlerin daha yüksek performans göstermesini gerekli kılmaktadır. Bu araştırmanın okullarda işlerini erteleyen ya da mazeretlerin arkasına sığınan, görev almaktan kaçan, bilinçli olarak performans engelleyici tutum ve davranışlar sergileyen öğretmenlerin kendilerini sabote etme davranışlarını daha iyi anlama noktasında yöneticilere ve araştırmacılara katkı sağlayacağı düşünülmektedir.

\subsection{Algılanan Örgütsel Destek}

Algılanan örgütsel destek, çalışanların çabalarının örgüt tarafından fark edilerek önemsenmesi, bu çabaların karşılığında örgütün de çalışanların refahına ve mutluluğuna yönelik girişimi olduğunun çalışanlar tarafından algılanması olarak ifade edilmektedir (Eisenberger, Hungtington, Hutchison ve Sowa, 1986; Rhoades ve Eisenberger, 2002). Destekleyici örgütlerde, çalışanlar karar verme süreçlerinde aktif olarak yer almakta, çalışanların farklı ve yeni fikirleri yönetim tarafından dikkate alınarak desteklenmektedir. Açık ve güçlü bir iletişim bulunan bu örgütlerde herkese adaletli ve eşit bir yaklaşım sergilenmektedir. Örgütsel destek algısı yüksek olan çalışanlar, hem kendisi hem de örgüt yararına birçok olumlu tutum ve davranışlar göstermektedir. Özdevecioğlu (2003) örgütsel desteği hisseden örgüt çalışanlarının mutluluğu, iş doyumu ve motivasyonunun arttığını belirtmiştir. Bir örgütte çalışanlarda örgütsel destek algısının oluşması, iş gören özelliklerine, yönetsel desteğe, örgütsel adalete, iş koşullarına, örgütsel ödüllere bağlı olup (Nayır, 2013; Rhoades ve Eisenberger, 2002), örgütün insan kaynağına ilişkin politika ve uygulamalarıyla doğrudan ilişkilidir.

Örgütsel destek kuramı, örgütün ve çalışanların yönetsel, sosyolojik ve psikolojik durumunu da ele almaktadır. Algılanan örgütsel destek ilk olarak örgütün amaçlarına ulaşmasında örgütün beklentileri ile çalışanların beklentileri arasında aracı bir rol görevi üstlenerek karşılıklılık normunu gerçekleştirmektedir. İkinci olarak şefkat, onay ve saygı ifadesinin bir göstergesi olarak algılanan örgütsel destek, örgüt üyeliği ve rolünün gerektirdiği sosyal kimlik ile çalışanların sosyo-duygusal ihtiyaçlarını karşılamaktadır. Üçüncü olarak olumlu algılanan örgütsel destek, çalışanların çabalarıyla örgütün performansını artırdığına ve ödüllendirildiğine ilişkin inancını güçlendirmekte (performans-ödül beklentisi); bu durum çalışanlarda iş doyumunu, morali, motivasyonu; örgütte ise artan duygusal bağlılıkla birlikte performansı, işe katılımı ve verimi artırmaktadır (Eğriboyun, 2013; Nayır, 2011; Rhoades \& Eisenberger, 2002).

\subsection{Kendini Sabotaj (Self-handicapping)}

Bazı bireyler özellikle yeni bir görev aldıklarında, yeterli kapasitede olsalar bile, başarı olasılıklarından şüphe ederek kaygı yaşarlar. Bu kaygı durumunu dışarı yansıtmamak için, başarısızlığını mantıklı gösterecek performans azaltıcı engeller oluştururlar. Başarısız olma durumlarını kendi kontrolü dışındaki durumsal faktörlere; başarılı olma durumlarını ise yeteneklerine ve çabalarına bağlama eğilimi gösterirler. Her iki durumda da birey başkalarının kendisi hakkındaki düşüncelerini manipüle etmektedir. Bireyin kendine hizmet eden bu stratejik girişimleri "kendini sabotaj" olarak adlandırılmaktadır. Abacı ve Akın (2011)'ın aktardığına göre Berglas ve Jones (1978) kendini sabotajı (self-handicapping) başarısızlığı dışsallaştırmaya ek olarak başarıyı da içselleştiren performans alanını seçme olarak tanımlamaktadır. Üzar ve diğerleri (2016)'ne göre ise bir görevin üstesinden gelinebilecek kapasiteye sahip olunmasına rağmen, bireyin endişe yaşaması ve yeterli kapasitede olmadığını düşünerek bahaneler bulma çabasıdır. Böylelikle kendisini haklı görmektedir. Akın (2012), Büyükgöze ve Gün (2015)'e göre kendini sabotajın amacı bireyin öz-saygı düzeyini korumak, öz-benliğine yönelik tehditleri ortadan kaldırmaktır.

Kendini sabotaj, sözel kendini sabotaj ve davranışsal kendini sabotaj olmak üzere iki şekilde görülmektedir. Sözel Kendini Sabotajda birey daha performans sergilemeden önce, depresyona girdiğini, kaygı yaşadığını, stresli olduğunu, koşulların iyi olmadığını, takım arkadaşlarının yetersiz ve uyumsuz olduğunu, hasta olduğunu sözel olarak iddia etmektedir. Abacı ve Akın (2011) davranışsal kendini sabotajda ise birey daha performans sergilemeden önce, alkol veya ilaç kullanma, yeteri kadar uyumama, işlerini erteleme, yeterli çaba göstermeme, yeteneğini engelleyici performanslar seçme gibi açık eylemler gerçekleştirmektedir ifadelerini kullanmışlardır.

Abacı ve Akın (2011); düşük öz-yeterliliği, düşük öz-saygıyı, olumsuz benlik algısını, dış denetim odaklılığı, hata yapma korkusunu, aşırı mükemmelliyetçiliği, yüksek sosyal kaygıyı, duygusal tatminsizliği, zor görev algısını, kaçınmacı kişilik bozukluğunu ve düşük özgüveni kendini sabotajın sebepleri arasında göstermektedirler. Üzar-Özçetin ve Hiçdurmaz (2016) kısa vadede bireyin öz-saygısını korurken; uzun süreli ve kronik şekilde kullanımında kişinin ruh sağlı̆̆ında bozulma, kaygı ve depresyon, 
kişilik bozukluğu, öz saygıda azalma, alkol-madde kullanımı, düşük yaşam doyumu, iç motivasyonda azalma ve performans kaybı gibi olumsuz sonuçlara yol açmaktadır demektedirler.

Özdemir (2014) örgüt amaçlarının gerçekleştirilmesi için bilgi, beceri ve yetenekleri ile örgüte katkı sağlayan çalışanlar, örgütün insan kaynaklarını oluşturmaktadır demekte ve eğitim örgütlerinde stratejik öneme sahip insan kaynaklarından biri öğretmenlerdir ifadesine vurgu yapmaktadır. Dolayısıyla öğretmenler eğitim hizmetlerinin etkili ve verimli bir şekilde gerçekleştirilmesinde önemli bir role sahiptir. Eğitim sisteminde stratejik bir öneme sahip öğretmenlere çalıştıkları kurum tarafından değer verilmesi moral, motivasyon, bağlılık ve iş doyumunu artırırken eğitim hizmetlerinin de verim ve kalitesinin artmasını sağlayacaktır. Öğretmenlik Mesleği Genel Yeterlikleri (2017) dahilinde mesleğe yönelik algıyı iyileştirmek ve mesleğin statüsünü güçlendirmek, öğretmenin niteliğini arttırmak amacıyla "mesleki bilgi, mesleki beceri, tutum ve değerler" alt boyutlarına yeterliliklere sahip olmaları gerekmektedir (Öğretmen Strateji Belgesi). Ancak tüm bu yeterliliklere rağmen öğretmenler, bireysel, örgütsel ya da göreve ilişkin algısından kaynaklanan sebeplerle çaba gerektiren işlerde bilinçli olarak düşük performans sergilemekte, kendini sabote etme eğilimi göstermektedir. Dolayısıyla performans engelleyici bir tutum ve davranış olan bu durum, başta akademik başarı olmak üzere eğitim öğretim faaliyetlerinde kalitenin düşmesine, okulda etkililik ve verimliliğin azalmasına yol açmaktadır.

Kendini sabotaj birçok psikolojik ve eğitsel değişkenle araştırılmasına rağmen, algılanan örgütsel destek değişkeni ile çalışılmadığı, ulusal literatürde kendini sabotaj konusunda az sayıda çalışmanın bulunduğu, bu çalışmaların çoğunluğunun eğitim-öğretim psikolojisi alanında ve lisans öğrencileri ile çalış1ldığ görülmüştür. Eğitim yönetimi alanında çalışılmamış olması, bir örgütsel davranış olarak değerlendirildiğinde, kendini sabote etme davranışının incelenmesinin; ulusal literatüre, yöneticilere ve performans engelleyici bir davranış olarak kendini sabotajın azaltılmasında öğretmenlere katkı sağlayacağı düşünülmektedir.

Bilinçli ve kasıtlı olarak gerçekleştirilen kendini sabote etme davranışı, bireyin kendisine, işine ve çalıştığı örgüte zarar vermektedir. Bu kapsamda eğitim kurumlarında rol model olması beklenen öğretmenlerin kendini sabote etmesine sebep olan faktörlerin incelenmesi önemli bir gereklilik olarak görülmektedir. Bu araştırma, öğretmenlerin kendini sabote etme düzeyleri ile algıladıkları örgütsel destek düzeyi arasındaki ilişkiyi belirlemek amacıyla yapılmıştır. Araştırmada cevap aranan sorular şunlardır:

1. Öğretmenlerin kendini sabote etme davranışı ne düzeydedir?

2. Öğretmenlerin algıladıkları örgütsel destek ne düzeydedir?

3. Öğretmenlerin kendini sabote etme düzeyi onların (a)cinsiyetlerine, (b)yaşlarına, (c)medeni durumlarına, (d)eğitim durumlarına, (e)branşlarına, (f)görev yaptı̆̆ı okul türüne, (g)kıdemlerine, (h)kurumdaki hizmet süresine göre farklılaşmakta mıdır?

4. Öğretmenlerin algıladıkları örgütsel destek düzeyi onların (a)cinsiyetlerine, (b)yaşlarına, (c)medeni durumlarına, (d)eğitim durumlarına, (e)branşlarına, (f)görev yaptığı okul türüne, (g)kıdemlerine, (h)kurumdaki hizmet süresine, (1)meslekte aldığı ödül sayısına göre farklılaşmakta midır?

5. Öğretmenlerin kendini sabote etme düzeyi ile algıladıkları örgütsel destek düzeyi arasında anlamlı bir ilişki var mıdır?

6. Öğretmenlerin algıladıkları örgütsel destek düzeyi, öğretmenlerin kendini sabote etme düzeyinin anlamlı bir yordayıcısı mıdır?

\section{YÖNTEM}

\subsection{Araştırma Modeli}

Araştırmada nicel araştırma tekniklerinden faydalanılmıştır. Nicel yöntemlerden ilişkisel tarama modeli bu çalışma için veri toplama deseni olarak tercih edilmiştir. Karasar (2017) a göre tarama modelleri, geçmişte ya da halen var olan bir durumu var olduğu şekliyle tespit etmeyi amaçlamaktadır. İlişkisel tarama modeli, değişkenler arasındaki ilişkileri belirlemek ve muhtemel sonuçları tahmin için kullanılır. İki veya daha fazla değişken arasındaki ilişki düzeyi istatistiksel testler kullanılarak ölçülmeye çalışılır. İlişkinin düzeyini belirlemek için korelasyon testi kullanılır. Korrelasyon iki veya daha fazla değişkenin (ayrı ayrı) birlikte tutarlı bir değişim gösterip göstermediğini ortaya koymaktadır (Metin,2014). Kendini sabote etme ve örgütsel desteğe ilişkin var olan durum ilişkisel tarama modeliyle tespit edilmeye çalış1lmıştır.

\subsection{Evren ve Örneklem}


Araştırmanın evrenini 2017-2018 eğitim-öğretim yılında Denizli'nin Pamukkale (2246) ve Merkezefendi (2132) ilçelerindeki Milli Eğitim Bakanlığı'na bağlı okullarda görev yapan 4359 öğretmen oluşturmaktadır. Araştırmanın örneklemini olasılık temelli örnekleme yöntemlerinden, basit tesadüfi örnekleme yapılarak ulaşılan 134 (\% 61,5)'ü kadın ve 84 (\% 38,5)'ü erkek olmak üzere toplam 218 öğretmen oluşturmaktadır.

\subsection{Veri Toplama Araçları}

Araştırmada veri toplamak amacıyla kişisel bilgi formu, Kendini Sabotaj Ölçeği ve Algılanan Örgütsel Destek Ölçeği kullanılmıştır. Her bir veri toplama aracına yönelik bilgiler aşağıda sunulmuştur.

Kişisel Bilgi Formu: Araştırmaya katılan öğretmenlerin cinsiyet, medeni durum, eğitim durumu, yaş, okul türü, kıdem, bulundukları kurumdaki hizmet süresi, branş ve ödül sayısı bilgilerini belirlemek amacıyla kişisel bilgi formu kullanılmıştır.

Kendini Sabotaj Ölçeği: Öğretmenlerin kendini sabote etme düzeylerini belirlemek amacıyla Jones ve Rhodewalt (1982) tarafından geliştirilen "Kendini Sabotaj Ölçeği" kullanılmıştır. Ölçeğin iç tutarlılık güvenirlik katsayısı .79'tur. Akın, Abacı ve Akın (2010) tarafindan Türkçe'ye uyarlanarak geçerlik ve güvenirlik çalışması yapılan ölçeğin Cronbach alfa iç tutarlılık güvenirlik katsayısı .90, test-tekrar test güvenirlik katsayısı ise .94 olarak bulunmuştur.

Algılanan Örgütsel Destek Ölçeği: $\mathrm{Bu}$ araştırmada, öğretmenlerin örgütsel destek algis1 düzeylerini belirlemek amaciyla Derinbay (2011) tarafindan geliştirilen "Algılanan Örgütsel Destek Ölçeği" kullanılmıştır. Ölçek üç boyutlu, 29 maddeden oluşan 5'li likert tipinde bir veri toplama aracıdır. Tüm ölçeğin Cronbach Alfa katsayısı .95, öğretimsel destek alt boyutu için .83, yönetsel destek alt boyutu için .89 , adalet alt boyutu için .92 olarak rapor edilmiştir. Yapılan güvenirlik analizi sonucunda algılanan örgütsel destek ölçeğinin Cronbach alfa katsayısı .96 ve öğretimsel destek alt boyutu için .85, yönetsel destek alt boyutu için .90, adalet alt boyutu için .94 olarak hesaplanmıştır.

\subsection{Verilerin Toplanması ve Analizi}

Ölçek formları çoğaltılarak katılımcı öğretmenlere dağıtılmış, toplanan formlar analiz edilmiştir. Verilerin analizi IBM SPSS 22.0 programı ile gerçekleştirilmiştir. Veriler normal dağılım gösterdiği için parametrik testler kullanılarak betimsel ve korelasyonel testler ile regresyon analizi yapılmıştır.

\section{BULGULAR}

Araştırmadan elde edilen veriler doğrultusunda öğretmenlerin kendini sabote etme davranışının düzeyi, öğretmenlerin algıladıkları örgütsel destek düzeyi, kendini sabote etme davranış ile demografik değişkenlerin ilişkisi, kendini sabote etme ile algılanan örgütsel destek arasındaki korelasyon ve algılanan örgütsel desteğin kendini sabote etme davranışını yordama gücü analiz edilerek yorumlanmıştır.

\section{1. Öğretmenlerin Kendini Sabote Etme Düzeyi}

Araştırmaya katılan öğretmenlerin kendini sabote etme davranışlarının düzeyi Tablo 1'de verilmektedir.

Tablo 1. Öğretmenlerin kendini sabote etme düzeyi

\begin{tabular}{ccccccc}
\hline & $\mathbf{N}$ & $\mathbf{m i n}$. & $\mathbf{m a x}$. & $\overline{\mathbf{x}}$ & Ss & Açıklama \\
\hline Kendini Sabotaj & 218 & 1,32 & 3,92 & 2,780 & .475 & $\begin{array}{c}\text { Kismen } \\
\text { kat1liyorum }\end{array}$ \\
\hline
\end{tabular}

Tablo 1'de öğretmenlerin kendini sabote etme davranışlarının ortalaması 2,78 olup, "klsmen katılıyorum" düzeyinde olduğu görülmektedir. Katılımcı öğretmenlerin kendini sabote etme eğilimlerine göre ortalaması en yüksek maddeler "11. Daha fazla çalışsaydım daha iyisini yapardım." $(\overline{\boldsymbol{x}}=4,189)$ ve "24. Çoğunlukla bir işi iyi yapacağıma ilişkin kaygı yaşadığımda iyi sonuç elde ederim." ( $\overline{\boldsymbol{x}}=4,023)$ maddeleri olmuştur. Ortalama değeri en düşük olan maddeler ise "5. Ne olursa olsun her zaman elimden gelenin en iyisini yapmaya çalışırım." ( $\overline{\boldsymbol{x}}=1,551)$ ve "20. Mantıklı düşünmemi ve doğru şeyler yapmamı engelleyecek herhangi bir madde veya ilaç almayl tercih etmem." ( $\overline{\boldsymbol{x}}=1,656)$ maddeleri olmuştur. 


\section{2. Öğretmenlerin Algıladıkları Örgütsel Destek Düzeyi}

Çalışmaya katılan öğretmenlerin algıladıkları örgütsel destek düzeyi Tablo 2'de verilmektedir.

Tablo 2: Öğretmenlerin algıladıkları örgütsel destek düzeyi

\begin{tabular}{ccccccl}
\hline & $\mathbf{N}$ & $\mathbf{m i n}$. & $\mathbf{m a x}$. & $\overline{\mathbf{x}}$ & \multicolumn{1}{c}{ Ss } & Açılama \\
\hline Algılanan Örgütsel Destek & 218 & 1,97 & 5,00 & 3,853 &, 595 & Kat1liyorum \\
1. Öğretimsel destek alt boyutu & 218 & 2,00 & 5,00 & 3,922 &, 566 & Kat1liyorum \\
2. Yönetsel destek alt boyutu & 218 & 2,00 & 5,00 & 3,844 &, 643 & Kat1liyorum \\
3. Adalet alt boyutu & 218 & 1,55 & 5,00 & 3,804 &, 709 & Kat1liyorum \\
\hline
\end{tabular}

Tablo 2'de de görüldüğü gibi araştırmaya katılan öğretmenlerin algıladıkları örgütsel destek ortalaması 3,853 olup, yüksek (katılıyorum) düzeydedir. Katılımcı öğretmenlerin algıladıkları örgütsel desteğe ilişkin belirttikleri görüşlere göre ortalama değeri en yüksek olan maddeler "10.Herhangi bir problemim nedeniyle (hastallk, aile vb.) işe gelemediğimde, okul yönetimi bu durumu anlayışla karşılar." $(\overline{\boldsymbol{x}}=4,262)$ ve "1. Işsimi etkileyen kararlar kendim alabilirim." ( $\overline{\boldsymbol{x}}=4,216)$ maddeleri olmuştur. Ortalama değeri en düşük olan maddeler ise "17. Okul yönetimi, her türlü eleştiriye açıktır." ( $\overline{\boldsymbol{x}}=3,491)$ ve "28.Bu okulda, sadece hak edenler ödüllendirilir.” ( $\overline{\boldsymbol{x}}=3,427)$ maddeleri olmuştur.

\section{3. Öğretmenlerin Kendini Sabote Etme Eğilimlerinin Demografik Değişkenler Açısından İncelenmesi}

Araştırmaya katılan öğretmenlerin kendini sabotaj düzeylerinin ve algıladıkları örgütsel destek düzeylerinin demografik değişkenlerden cinsiyet, medeni durum ve eğitim durumu değişkenleri ile ilişkisi t-testi ile; katılımcıların kendini sabotaj düzeylerinin ve algıladıkları örgütsel destek düzeylerinin yaş, okul türü, kıdem, kurumdaki hizmet süresi, branş ve ödül sayısı değişkenleri ile ilişkisi ANOVA ile test edilmiştir.

Katılımcı öğretmenlerin kendini sabote etme düzeylerinin cinsiyet, medeni durum ve eğitim durumu değişkenine göre istatistiksel olarak farklılaşıp farklılaşmadığını belirlemek amacıyla yapılan $t$ testi analizi sonucunda elde edilen bulgular Tablo 3 'te verilmektedir.

Tablo 3: Öğretmenlerin kendini sabote etme düzeylerinin cinsiyet, medeni durum ve eğitim durumu değişkenine göre incelenmesi

\begin{tabular}{|c|c|c|c|c|c|c|c|c|}
\hline & Değişken & Gruplar & $\mathbf{N}$ & $\overline{\mathbf{x}}$ & Ss & $\mathbf{t}$ & df & p \\
\hline \multirow{3}{*}{$\begin{array}{l}\text { Kendini } \\
\text { Sabotaj }\end{array}$} & Cinsiyet & $\begin{array}{l}\text { Kadın } \\
\text { Erkek }\end{array}$ & $\begin{array}{c}134 \\
84\end{array}$ & $\begin{array}{l}2,744 \\
2,837\end{array}$ & $\begin{array}{l}, 481 \\
, 464\end{array}$ & $-1,400$ & 216 & ,163 \\
\hline & $\begin{array}{l}\text { Medeni } \\
\text { Durum }\end{array}$ & $\begin{array}{l}\text { Evli } \\
\text { Bekar }\end{array}$ & $\begin{array}{c}171 \\
47\end{array}$ & $\begin{array}{l}2,792 \\
2,735\end{array}$ & $\begin{array}{l}, 480 \\
, 461\end{array}$ &, 723 & 216 &, 470 \\
\hline & $\begin{array}{l}\text { Eğitim } \\
\text { Durumu }\end{array}$ & $\begin{array}{l}\text { Lisans } \\
\text { Lisansüstü }\end{array}$ & $\begin{array}{c}197 \\
21\end{array}$ & $\begin{array}{l}2,787 \\
2,711\end{array}$ & $\begin{array}{l}, 477 \\
, 464\end{array}$ &, 702 & 216 & ,483 \\
\hline
\end{tabular}

$(p<.05)$

Tablo 3'te görüldüğg̈ gibi katılımcı öğretmenlerin kendini sabotaj eğilimleri ile cinsiyet, medeni durum ve eğitim durumu arasındaki farkı belirlemek amacıyla yapılan $t$ testi sonucunda, öğretmenlerin kendini sabote etme eğilimleri ile cinsiyet $\left(t_{(216)}=-1,400 ; p<.05\right)$, medeni durum $\left(t_{(216)}=, 723 ; p<.05\right)$ ve eğitim durumu $\left(t_{(216)}=, 702 ; p<.05\right)$ değişkelerine göre istatistiksel olarak anlamlı bir fark göstermemektedir. Bu bulgular, kadın-erkek, evli-bekar, lisans ve yüksek lisans mezunu öğretmenlerin kendini sabote etme eğilimlerinin benzer düzeyde olduğunu göstermektedir.

Katılımcı öğretmenlerin algıladıkları örgütsel destek düzeylerinin cinsiyet, medeni durum ve eğitim durumu değişkenine göre istatistiksel olarak farklılaşıp farklılaşmadığını belirlemek amacıyla yapılan $t$ testi analizi sonucunda elde edilen bulgular Tablo 4'te verilmektedir. 
Tablo4: Öğretmenlerin alglladıkları örgütsel destek düzeylerinin cinsiyet, medeni durum ve eğitim durumu değişkenine göre incelenmesi

\begin{tabular}{|c|c|c|c|c|c|c|c|c|}
\hline & Değișken & Gruplar & $n$ & $\overline{\mathbf{x}}$ & Ss & $t$ & df & $p$ \\
\hline \multirow{3}{*}{$\begin{array}{l}\text { Algılanan } \\
\text { Örgütsel } \\
\text { Destek }\end{array}$} & Cinsiyet & $\begin{array}{l}\text { Kadın } \\
\text { Erkek }\end{array}$ & $\begin{array}{c}134 \\
84\end{array}$ & $\begin{array}{l}3,8163 \\
3,9113\end{array}$ & $\begin{array}{l}661058 \\
, 56889\end{array}$ & $-1,148$ & 216 & ,252 \\
\hline & $\begin{array}{l}\text { Medeni } \\
\text { Durum }\end{array}$ & $\begin{array}{l}\text { Evli } \\
\text { Bekar }\end{array}$ & $\begin{array}{c}171 \\
47\end{array}$ & $\begin{array}{l}3,8332 \\
3,9244\end{array}$ & $\begin{array}{l}, 59790 \\
, 58668\end{array}$ &,- 930 & 216 & ,353 \\
\hline & $\begin{array}{l}\text { Ĕgitim } \\
\text { Durumu }\end{array}$ & $\begin{array}{l}\text { Lisans } \\
\text { Lisansüstü }\end{array}$ & $\begin{array}{c}197 \\
21\end{array}$ & $\begin{array}{l}3,8724 \\
3,6700\end{array}$ & $\begin{array}{l}, 58853 \\
, 64212\end{array}$ & 1,485 & 216 & ,139 \\
\hline
\end{tabular}

Tablo 4'te görüldüğü gibi katılımcı öğretmenlerin algıladıkları örgütsel destek düzeyi ile cinsiyet, medeni durum ve eğitim durumu arasındaki fark1 belirlemek amaciyla yapılan $t$ testi sonucunda, öğretmenlerin algiladıkları örgütsel destek düzeyi ile cinsiyet $\left(t_{(216)}=-1,148 ; p<.05\right)$, medeni durum $\left(t_{(216)}\right.$ $=-, 930 ; p<.05)$ ve eğitim durumu $\left(t_{(216)}=1,485 ; p<.05\right)$ değişkelerine göre istatistiksel olarak anlamlı bir fark göstermemektedir. Bu bulgular, kadın-erkek, evli-bekar, lisans ve yüksek lisans mezunu öğretmenlerin algıladıkları örgütsel desteğin benzer düzeyde olduğunu göstermektedir.

Araştırmaya katılan öğretmenlerin kendini sabote etme eğilimlerinin yaş değişkenine göre istatistiksel olarak farklılaşıp farklılaşmadığını belirlemek amacıyla yapılan Tek Yönlü Varyans (ANOVA) analizi sonucunda elde edilen bulgular Tablo 5 'te verilmektedir.

Tablo 5: Öğretmenlerin kendini sabote etme düzeyinin yaş değişkenine göre incelenmesi

\begin{tabular}{|c|c|c|c|c|c|c|c|c|c|c|c|}
\hline & Yaş & $\mathbf{n}$ & $\overline{\mathbf{x}}$ & $\begin{array}{l}\text { Standart } \\
\text { Sapma }\end{array}$ & $\begin{array}{c}\text { Varyansın } \\
\text { KaynağI } \\
\end{array}$ & $\begin{array}{l}\text { Kareler } \\
\text { Toplamı } \\
\end{array}$ & df & $\begin{array}{c}\text { Kareler } \\
\text { Ortalaması } \\
\end{array}$ & $\mathbf{F}$ & $\mathbf{p}$ & Fark \\
\hline \multirow{5}{*}{ 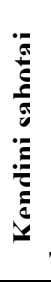 } & 24-32 yaş & 56 & 2,8714 & ,46671 & Gruplararası & 1,199 & 3 & ,400 & & & \\
\hline & 33-41 yaş & 90 & 2,7600 & , 45670 & Gruplariçi & 47,893 & 214 &, 224 & 1,785 & 151 & - \\
\hline & $42-50$ yaş & 56 & 2,6871 & ,49233 & Toplam & 49,092 & 217 & & & & \\
\hline & $\begin{array}{l}51 \text { ve üstü } \\
\text { yaș }\end{array}$ & 16 & 2,8950 & ,51761 & & & & & & & \\
\hline & Toplam & 218 & 2,7798 & ,47564 & & & & & & & \\
\hline
\end{tabular}

Tablo 5'e göre araştırmaya katılan öğretmenlerin kendini sabotaj eğilimleri ile yaş değişkeni arasındaki farkı belirlemek amacıyla yapılan varyans analizi sonucunda, öğretmenlerin kendini sabote etmeleri ile yaş arasında istatistiksel açıdan anlamlı bir farklılık olmadığ görülmüştür $\left(F_{(3,214)}=1,785 ; p<\right.$ $.05)$. Araştırmaya katılan öğretmenlerin algıladıkları örgütsel destek düzeylerinin yaş değişkenine göre istatistiksel olarak farklılaşıp farklılaşmadığını belirlemek amacıyla yapılan Tek Yönlü Varyans (ANOVA) analizi sonucunda elde edilen bulgular Tablo 6'da verilmektedir.

Tablo 6: Öğretmenlerin algıladıkları örgütsel destek düzeyinin yaş değişkenine göre incelenmesi

\begin{tabular}{|c|c|c|c|c|c|c|c|c|c|c|c|}
\hline & Yaş & $\mathbf{n}$ & $\overline{\mathbf{x}}$ & $\begin{array}{c}\text { Standart } \\
\text { Sapma }\end{array}$ & $\begin{array}{l}\text { Varyansın } \\
\text { Kaynağı }\end{array}$ & $\begin{array}{c}\text { Kareler } \\
\text { Toplamı }\end{array}$ & df & $\begin{array}{c}\text { Kareler } \\
\text { Ortalam } \\
\text { ası } \\
\end{array}$ & $\mathbf{F}$ & $\mathbf{p}$ & Fark \\
\hline \multirow{5}{*}{ 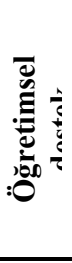 } & 24-32 yaş & 56 & 3,8968 & ,55651 & \multirow{5}{*}{$\begin{array}{l}\text { Gruplararas } \\
\text { I } \\
\text { Gruplariçi } \\
\text { Toplam }\end{array}$} & 2,250 & 3 &, 750 & 2,390 & ,070 & - \\
\hline & \multirow{4}{*}{$\begin{array}{l}33-41 \text { yaş } \\
42-50 \text { yaş } \\
51 \text { ve üstü } \\
\text { yaş } \\
\text { Toplam }\end{array}$} & 90 & 3,8580 & ,56460 & & 67,172 & 214 & ,314 & & & \\
\hline & & 56 & 3,9524 & ,56808 & & 69,422 & 217 & & & & \\
\hline & & 16 & 4,2569 & ,51754 & & & & & & & \\
\hline & & 218 & 3,9215 &, 56561 & & & & & & & \\
\hline \multirow{5}{*}{ 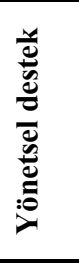 } & 24-32 yaş & 56 & 3,8016 & ,62306 & \multirow{5}{*}{$\begin{array}{l}\text { Gruplararas } \\
\text { I } \\
\text { Gruplariçi } \\
\text { Toplam }\end{array}$} &, 755 & 3 & ,252 & ,605 & ,612 & - \\
\hline & \multirow{4}{*}{$\begin{array}{l}33-41 \text { yaş } \\
42-50 \text { yaş } \\
51 \text { ve üstü } \\
\text { yaş } \\
\text { Toplam }\end{array}$} & 90 & 3,8222 & ,71618 & & 89,004 & 214 & ,416 & & & \\
\hline & & 56 & 3,8671 & ,53953 & & 89,759 & 217 & & & & \\
\hline & & 16 & 4,0347 & 63209, & & & & & & & \\
\hline & & 218 & 3,8440 & ,64315 & & & & & & & \\
\hline \multirow{2}{*}{$\sum^{\frac{\pi}{2}}$} & 24-32 yaş & 56 & 3,7662 & ,70244 & \multirow{2}{*}{$\begin{array}{l}\text { Gruplararas } \\
\text { I } \\
\text { Gruplariçi }\end{array}$} & 2,313 & 3 &, 771 & 1,546 & ,204 & - \\
\hline & 33-41 yaş & 90 & 3,7182 & ,80104 & & 106,750 & 214 & ,499 & & & \\
\hline
\end{tabular}




\begin{tabular}{|c|c|c|c|c|c|c|c|c|c|c|c|}
\hline & $\begin{array}{l}42-50 \text { yaş } \\
51 \text { ve üstü } \\
\text { yaş } \\
\text { Toplam }\end{array}$ & $\begin{array}{c}56 \\
16 \\
218\end{array}$ & $\begin{array}{l}3,9107 \\
4,0455 \\
\mathbf{3 , 8 0 4 0}\end{array}$ & $\begin{array}{l}, 54724 \\
, 63420 \\
, \mathbf{7 0 8 9 4}\end{array}$ & Toplam & 109,064 & 217 & & & & \\
\hline \multirow{5}{*}{ 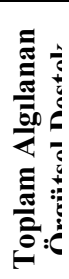 } & $24-32$ yaş & 56 & 3,8177 & ,57433 & \multirow{5}{*}{$\begin{array}{l}\text { Gruplararas } \\
\text { I } \\
\text { Gruplariçi } \\
\text { Toplam }\end{array}$} & 1,605 & 3 &, 535 & \multirow[t]{5}{*}{1,521} & \multirow[t]{5}{*}{,210 } & \multirow[t]{5}{*}{ - } \\
\hline & $33-41$ yaş & 90 & 3,7939 & 65555 & & 75,306 & 214 &, 352 & & & \\
\hline & $42-50$ yaş & 56 & 3,9101 &, 50635 & & 76,911 & 217 & & & & \\
\hline & $\begin{array}{l}51 \text { ve üstü } \\
\text { yaş }\end{array}$ & 16 & 4,1078 & ,56659 & & & & & & & \\
\hline & Toplam & 218 & 3,8529 & ,59534 & & & & & & & \\
\hline
\end{tabular}

Tablo 6'ya göre araştırmaya katılan öğretmenlerin algıladıkları örgütsel destek düzeyi ile yaş değişkeni arasındaki farkı belirlemek amacıyla yapılan varyans analizi sonucunda, öğretmenlerin "öğretimsel destek" $\left(F_{(3,214)}=2,390 ; p<.05\right)$, "yönetsel destek" $\left(F_{(3,214)}=, 605 ; p<.05\right)$, "adalet" $\left(F_{(3,214)}\right.$ $=1,46 ; p<.05)$ ve "toplam algılanan örgütsel destek" $\left(F_{(3,214)}=1,521 ; p<.05\right)$ düzeyi ile yaş arasında istatistiksel açıdan anlamlı bir farklılık olmadığı görülmüştür.

Araştırmaya katılan öğretmenlerin kendini sabote etme eğilimlerinin okul türü değişkenine göre istatistiksel olarak farklılaşıp farklılaşmadığını belirlemek amacıyla yapılan Tek Yönlü Varyans (ANOVA) analizi sonucunda elde edilen bulgular Tablo 7'de verilmektedir.

Tablo 7: Öğretmenlerin kendini sabote etme düzeyinin okul türü değişkenine göre incelenmesi

\begin{tabular}{|c|c|c|c|c|c|c|c|c|c|c|c|}
\hline & $\begin{array}{l}\text { Okul } \\
\text { Türü }\end{array}$ & $\mathbf{n}$ & $\overline{\mathbf{x}}$ & $\begin{array}{l}\text { Standart } \\
\text { Sapma }\end{array}$ & $\begin{array}{l}\text { Varyans } \\
\text { Kaynağı }\end{array}$ & $\begin{array}{l}\text { Kareler } \\
\text { Toplamı }\end{array}$ & df & $\begin{array}{l}\text { Kareler } \\
\text { Ortalam } \\
\text { ası } \\
\end{array}$ & $\mathbf{F}$ & $\mathbf{p}$ & Fark \\
\hline \multirow{4}{*}{ 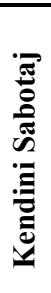 } & İlkokul & 50 & 2,7216 & ,54636 & $\begin{array}{l}\text { Gruplarara } \\
\text { S1 }\end{array}$ & ,498 & 2 & ,249 & 1,102 & 334 & - \\
\hline & Ortaokul & 126 & 2,7737 & ,44749 & Gruplariçi & 48,594 & 215 & ,226 & & & \\
\hline & Lise & 42 & 2,8676 & ,46685 & Toplam & 49,092 & 217 & & & & \\
\hline & Toplam & 218 & 2,7798 & ,47564 & & & & & & & \\
\hline
\end{tabular}

$\overline{(p<.05)}$

Tablo 7'ye göre araştırmaya katılan öğretmenlerin kendini sabotaj eğilimleri ile görev yaptıkları okul türü değişkeni arasındaki farkı belirlemek amacıyla yapılan varyans analizi sonucunda, öğretmenlerin kendini sabote etme eğilimleri ile okul türü arasında istatistiksel açıdan anlamlı bir farklılık olmadığı görülmüştür $\left(F_{(2,215)}=1,102 ; p<.05\right)$. Araştırmaya katılan öğretmenlerin algıladıkları örgütsel destek düzeylerinin okul türü değişkenine göre istatistiksel olarak farklılaşıp farklılaşmadığını belirlemek amacıyla yapılan Tek Yönlü Varyans (ANOVA) analizi sonucunda elde edilen bulgular Tablo 8'de verilmektedir.

Tablo 8: Öğretmenlerin algıladıklarl örgütsel destek düzeyinin okul türü değişkenine göre incelenmesi

\begin{tabular}{|c|c|c|c|c|c|c|c|c|c|c|c|}
\hline & $\begin{array}{l}\text { Okul } \\
\text { Türü }\end{array}$ & $\mathbf{n}$ & $\overline{\mathbf{x}}$ & $\begin{array}{c}\text { Standart } \\
\text { Sapma }\end{array}$ & $\begin{array}{l}\text { Varyans } \\
\text { Kaynağı }\end{array}$ & $\begin{array}{c}\text { Kareler } \\
\text { Toplam } \\
\text { I }\end{array}$ & df & $\begin{array}{c}\text { Kareler } \\
\text { Ortala } \\
\text { ması }\end{array}$ & $\mathbf{F}$ & $\mathbf{p}$ & $\begin{array}{c}\text { Farkın } \\
\text { Kaynağı }\end{array}$ \\
\hline \multirow{4}{*}{ 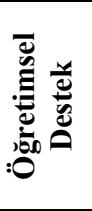 } & İlkokul & 50 & 3,9089 & ,60513 & $\begin{array}{l}\text { Gruplarara } \\
\text { si }\end{array}$ &, 357 & 2 &, 179 & ,556 & ,574 & - \\
\hline & Ortaokul & 126 & 3,9515 &, 56227 & Gruplariçi & 69,065 & 215 &, 321 & & & \\
\hline & Lise & 42 & 3,8466 & ,53199 & Toplam & 69,422 & 217 & & & & \\
\hline & Toplam & 218 & 3,9215 & ,56561 & & & & & & & \\
\hline \multirow{4}{*}{ 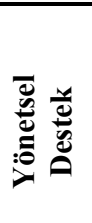 } & İlkokul & 50 & 3,8000 & ,72392 & $\begin{array}{l}\text { Gruplarara } \\
\text { si }\end{array}$ & 4,697 & 2 & 2,349 & 5,936 & ,003* & \multirow{4}{*}{$\begin{array}{l}\text { (Ortaokul } \\
\text { )- (Lise)* }\end{array}$} \\
\hline & Ortaokul & 126 & 3,9524 & ,62703 & Gruplariçi & 85,062 & 215 & ,396 & & & \\
\hline & Lise & 42 & 3,5714 & ,49967 & Toplam & 89,759 & 217 & & & & \\
\hline & To & 218 & 3,8440 & 64315, & & & & & & & \\
\hline
\end{tabular}




\begin{tabular}{|c|c|c|c|c|c|c|c|c|c|c|c|}
\hline \multirow{4}{*}{ 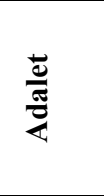 } & İlkokul & 50 & 3,8727 &, 74514 & $\begin{array}{l}\text { Gruplarara } \\
\text { si }\end{array}$ & 3,716 & & & 3,792 &, $024 *$ & \multirow{4}{*}{$\begin{array}{c}\text { (Ortaokul) } \\
\text {-(Lise)* }\end{array}$} \\
\hline & Ortaokul & 126 & 3,8658 & ,68425 & Gruplariçi & 105,34 & 215 & ,490 & & & \\
\hline & Lise & 42 & 3,5368 & 69170 & Toplam & 109,06 & 217 & & & & \\
\hline & Toplam & 218 & 3,8040 & ,70894 & & & & & & & \\
\hline \multirow{4}{*}{ 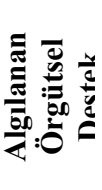 } & İlkokul & 50 & 3,8614 & ,64888 & $\begin{array}{l}\text { Gruplarara } \\
\text { s1 }\end{array}$ & 2,397 & 2 & 1,199 & 3,458 & $\begin{array}{c}\mathbf{0 3 3} \\
*\end{array}$ & \multirow{4}{*}{$\begin{array}{c}\text { (Ortaokul) } \\
\quad-(\text { Lise)* }\end{array}$} \\
\hline & Ortaokul & 126 & 3,9193 &, 58241 & Gruplariçi & 74,514 & 215 & ,347 & & & \\
\hline & Lise & 42 & 3,6437 & ,52922 & Toplam & 76,911 & 217 & & & & \\
\hline & Toplam & 218 & 3,8529 & ,59534 & & & & & & & \\
\hline
\end{tabular}

Tablo 8'e göre araştırmaya katılan öğretmenlerin algıladıkları örgütsel destek düzeyleri ile görev yaptıkları okul türü değişkeni arasındaki farkı belirlemek amacıyla yapılan varyans analizi sonucunda öğretmenlerin "yönetsel destek" alt boyutu $\left(F_{(2,215)}=5,936 ; p<.05\right)$, "adalet" alt boyutu $\left(F_{(2,215)}=3,792\right.$; $p<.05)$ ve "toplam algılanan örgütsel destek" $\left(F_{(2,215)}=3,458 ; p<.05\right)$ düzeyleri ile okul türü arasinda istatistiksel açıdan anlamlı bir farklılık olduğu görülmüştür. Farkın hangi gruplar arasında bulunduğunu belirlemek amacıyla post hoc testlerinden biri olan Tukey testinden yararlanılmıştır. Buna göre "yönetsel destek" alt boyutunda ortaokul öğretmenlerinin $(\overline{\boldsymbol{x}}=3.9524)$, lise öğretmenlerine $(\overline{\boldsymbol{x}}=3.5714)$ göre; "adalet" alt boyutunda ortaokul öğretmenlerinin $(\overline{\boldsymbol{x}}=3.8628)$, lise öğretmenlerine $(\overline{\boldsymbol{x}}=3.5368)$ göre ve "algılanan örgütsel destek toplamında" ise ortaokul öğretmenlerinin $(\overline{\boldsymbol{x}}=3.9193)$, lise öğretmenlerine $(\overline{\boldsymbol{x}}=3.6437)$ göre daha fazla örgütsel destek algısına sahip oldukları belirlenmiştir. Araştırmaya katılan öğretmenlerin kendini sabote etme eğilimlerinin meslekteki kıdem değişkenine göre istatistiksel olarak farklılaşıp farklılaşmadığını belirlemek amacıyla yapılan Tek Yönlü Varyans (ANOVA) analizi sonucunda elde edilen bulgular Tablo 9'da verilmektedir.

Tablo 9: Öğretmenlerin kendini sabote etme düzeyinin kıdem değişkenine göre incelenmesi

\begin{tabular}{|c|c|c|c|c|c|c|c|c|c|c|c|}
\hline & Kıdem & $\mathbf{n}$ & $\overline{\mathbf{x}}$ & $\begin{array}{l}\text { Standart } \\
\text { Sapma }\end{array}$ & $\begin{array}{l}\text { Varyans } \\
\text { Kaynağı }\end{array}$ & $\begin{array}{l}\text { Kareler } \\
\text { Toplamı }\end{array}$ & df & $\begin{array}{l}\text { Kareler } \\
\text { Ortalam } \\
\text { ası }\end{array}$ & $\mathbf{F}$ & $\mathbf{p}$ & Fark \\
\hline \multirow{6}{*}{ 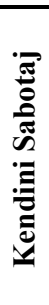 } & $1-5$ yıl & 29 & 2,8386 & ,42541 & Gruplararas & 1,452 & 4 &, 362 & \multirow{6}{*}{1,621} & \multirow{6}{*}{, 170} & \multirow[t]{6}{*}{ - } \\
\hline & 6-10 yıl & 46 & 2,8322 & ,48337 & Gruplariçi & 47,642 & 213 & 224 & & & \\
\hline & 11-15 yll & 43 & 2,8335 & ,38057 & Toplam & 49,092 & 217 & & & & \\
\hline & $16-20$ yıl & 49 & 2,6310 & ,55035 & & & & & & & \\
\hline & $\begin{array}{l}21 \quad \text { ve } \\
\text { üstü yıl }\end{array}$ & 51 & 2,7969 & ,47832 & & & & & & & \\
\hline & Toplam & 218 & 2,7798 & ,47564 & & & & & & & \\
\hline
\end{tabular}

$(p<.05)$

Tablo 9'a göre araştırmaya katılan öğretmenlerin kendini sabotaj eğilimleri ile mesleki kıdem değişkeni arasındaki farkı belirlemek amacıyla yapılan varyans analizi sonucunda, öğretmenlerin kendini sabote etmeleri ile meslekteki kıdem süreleri arasında istatistiksel açıdan anlamlı bir farklılık olmadığı görülmüştür $\left(F_{(4,213)}=1,621 ; p<.05\right)$. Araştırmaya katılan öğretmenlerin algıladıkları örgütsel destek düzeylerinin mesleki kıdem değişkenine göre istatistiksel olarak farklılaşıp farklılaşmadığını belirlemek amacıyla yapılan Tek Yönlü Varyans (ANOVA) analizi sonucunda elde edilen bulgular Tablo 10'da verilmektedir.

Tablo 10: Öğretmenlerin algıladıkları örgütsel destek düzeyinin kıdem değişkenine göre incelenmesi

\begin{tabular}{|c|c|c|c|c|c|c|c|c|c|c|c|}
\hline & Kıdem & $\mathbf{n}$ & $\overline{\mathbf{x}}$ & $\begin{array}{c}\text { Standart } \\
\text { Sapma }\end{array}$ & $\begin{array}{l}\text { Varyans } \\
\text { Kaynağı }\end{array}$ & $\begin{array}{c}\text { Kareler } \\
\text { Toplamı }\end{array}$ & df & $\begin{array}{c}\text { Karele } \\
\mathbf{r} \\
\text { Ortala } \\
\text { masi }\end{array}$ & $\mathbf{F}$ & $\mathbf{p}$ & $\begin{array}{c}\text { Farkın } \\
\text { Kaynağı }\end{array}$ \\
\hline \multirow{6}{*}{ 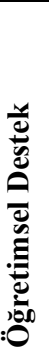 } & $1-5 \mathrm{yll}$ & 29 & 3,8582 & ,50735 & $\begin{array}{l}\text { Gruplarar } \\
\text { ası }\end{array}$ & ,953 & 4 & ,238 & ,741 & 565 & - \\
\hline & 6-10 yıl & 46 & 3,9251 & 65297 & Gruplariçi & 68,470 & 213 & 321 & & & \\
\hline & 11-15 yll & 43 & 3,8269 & 48753 & Toplam & 69,422 & 217 & & & & \\
\hline & 16-20 yıl & 49 & 3,9433 & ,56661 & & & & & & & \\
\hline & $\begin{array}{l}21 \quad \text { ve } \\
\text { üstü yll }\end{array}$ & 51 & 4,0131 & 57763 & & & & & & & \\
\hline & Toplam & $\begin{array}{c}21 \\
8\end{array}$ & 3,9215 & ,56561 & & & & & & & \\
\hline
\end{tabular}




\begin{tabular}{|c|c|c|c|c|c|c|c|c|c|c|c|}
\hline \multirow{6}{*}{ 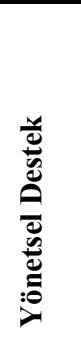 } & $1-5$ yil & 29 & 3,7854 & 64988 & $\begin{array}{l}\text { Gruplarar } \\
\text { ası }\end{array}$ & 1,022 & 4 & ,256 & ,614 & ,653 & - \\
\hline & 6-10 yıl & 46 & 3,8502 & 64031 & Gruplariçi & 88,737 & 213 & ,417 & & & \\
\hline & 11-15 yll & 43 & 3,7364 & 67063 & Toplam & 89,759 & 217 & & & & \\
\hline & $16-20$ yll & 49 & 3,8798 & 69494 & & & & & & & \\
\hline & $\begin{array}{l}21 \quad \text { ve } \\
\text { üstü yıl }\end{array}$ & 51 & 3,9281 &, 57255 & & & & & & & \\
\hline & Toplam & $\begin{array}{c}21 \\
8 \\
\end{array}$ & 3,8440 & ,64315 & & & & & & & \\
\hline \multirow{6}{*}{ 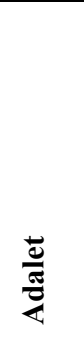 } & $1-5$ yil & 29 & 3,6959 & ,62856 & \multirow{6}{*}{$\begin{array}{l}\text { Gruplarar } \\
\text { ası } \\
\text { Gruplariçi } \\
\text { Toplam }\end{array}$} & 3,904 & 4 & ,976 & \multirow[t]{6}{*}{$\begin{array}{c}1,97 \\
7\end{array}$} & \multirow[t]{6}{*}{,099 } & \multirow[t]{6}{*}{ - } \\
\hline & 6-10 yil & 46 & 3,8123 & ,75561 & & 105,160 & 213 & ,494 & & & \\
\hline & 11-15 yll & 43 & 3,6089 &, 75633 & & 109,064 & 217 & & & & \\
\hline & 16-20 yil & 49 & 3,8312 & ,76669 & & & & & & & \\
\hline & $\begin{array}{l}21 \quad \text { ve } \\
\text { üstü yıl }\end{array}$ & 51 & 3,9964 & ,56859 & & & & & & & \\
\hline & Toplam & $\begin{array}{c}21 \\
8 \\
\end{array}$ & 3,8040 & ,70894 & & & & & & & \\
\hline \multirow{6}{*}{ 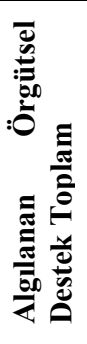 } & $1-5$ yil & 29 & 3,7741 & ,53178 & \multirow{6}{*}{$\begin{array}{l}\text { Gruplarar } \\
\text { ası } \\
\text { Gruplariçi } \\
\text { Toplam }\end{array}$} & 1,854 & 4 & ,464 & \multirow[t]{6}{*}{$\begin{array}{c}1,31 \\
6\end{array}$} & \multirow[t]{6}{*}{,265 } & \multirow[t]{6}{*}{ - } \\
\hline & 6-10 yıl & 46 & 3,8591 & 63620 & & 75,057 & 213 &, 352 & & & \\
\hline & 11-15 yll & 43 & 3,7161 & ,59507 & & 76,911 & 217 & & & & \\
\hline & $16-20$ yll & 49 & 3,8811 & ,64342 & & & & & & & \\
\hline & $\begin{array}{l}21 \quad \text { ve } \\
\text { üstü yıl }\end{array}$ & 51 & 3,9804 & ,53257 & & & & & & & \\
\hline & Toplam & $\begin{array}{c}21 \\
8\end{array}$ & 3,8529 & ,59534 & & & & & & & \\
\hline
\end{tabular}

$(p<.05)$

Tablo 10'a göre araştırmaya katılan öğretmenlerin algıladıkları örgütsel destek düzeyleri ile mesleki kıdem değişkeni arasındaki farkı belirlemek amacıyla yapılan varyans analizi sonucunda, "öğretimsel destek" $\left(F_{(4,213)}=, 741 ; p<.05\right)$, "yönetsel destek" $\left(F_{(4,213)}=, 614 ; p<.05\right)$, "adalet" $\left(F_{(4,213)}=1,977 ; p<.05\right)$ ve "toplam algılanan örgütsel destek" $\left(F_{(4,213)}=1,316 ; p<.05\right)$ düzeyi ile meslekteki kıdem süreleri arasında istatistiksel açıdan anlamlı bir farklılık olmadığı görülmüştür. Araştırmaya katılan öğretmenlerin kendini sabote etme eğilimlerinin görev yaptığ 1 okuldaki hizmet süresi değişkenine göre istatistiksel olarak farklılaşıp farklılaşmadığını belirlemek amacıyla yapılan Tek Yönlü Varyans (ANOVA) analizi sonucunda elde edilen bulgular Tablo 11'de verilmektedir.

Tablo 11: Öğretmenlerin kendini sabote etme düzeyinin görev yaptığı okuldaki hizmet süresi değişkenine göre incelenmesi

\begin{tabular}{|c|c|c|c|c|c|c|c|c|c|c|c|}
\hline & Kıdem & $\mathbf{n}$ & $\overline{\mathbf{x}}$ & $\begin{array}{l}\text { Standart } \\
\text { Sapma }\end{array}$ & $\begin{array}{l}\text { Varyans } \\
\text { Kaynağı }\end{array}$ & $\begin{array}{c}\text { Kareler } \\
\text { Toplamı }\end{array}$ & df & $\begin{array}{c}\text { Kareler } \\
\text { Ortalama } \\
\text { sı } \\
\end{array}$ & $\mathbf{F}$ & $\mathbf{p}$ & Fark \\
\hline \multirow{4}{*}{ 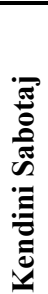 } & 1-3 yıl & 80 & 2,8250 &, 44712 & $\begin{array}{l}\text { Gruplararas } \\
\text { I }\end{array}$ & 1,429 & 2 &, 715 & 3,224 &, 052 & - \\
\hline & 4-6 yıl & 82 & 2,8298 & ,48523 & Gruplariçi & 47,663 & 215 & ,222 & & & \\
\hline & $\begin{array}{l}7 \text { ve üstü } \\
\text { yıl }\end{array}$ & 56 & 2,6421 &, 48238 & Toplam & 49,092 & 217 & & & & \\
\hline & Toplam & 218 & 2,7798 &, 47564 & & & & & & & \\
\hline
\end{tabular}

$(p<.05)$

Tablo 11'de görüldüğü gibi araştırmaya katılan öğretmenlerin kendini sabotaj eğilimleri ile görev yaptıkları kurumdaki hizmet süreleri arasındaki farkı belirlemek amacıyla yapılan varyans analizi sonucunda, ögretmenlerin kendini sabote etmeleri ile görev yaptıkları kurumlardaki hizmet süreleri arasında istatistiksel açıdan anlamlı bir farklılık olmadığı görülmüştür $\left(F_{(2,215)}=3,224 ; p>.05\right)$. Araştırmaya katılan öğretmenlerin algıladıkları örgütsel destek düzeylerinin görev yaptıkları kurumdaki hizmet süresi değişkenine göre istatistiksel olarak farklılaşıp farklılaşmadığını belirlemek amacıyla yapılan Tek Yönlü Varyans (ANOVA) analizi sonucunda elde edilen bulgular Tablo 12'de verilmektedir. 
Tablo 12: Öğretmenlerin algıladıkları örgütsel destek düzeyinin görev yaptıkları okuldaki hizmet süresi değişkenine göre incelenmesi

\begin{tabular}{|c|c|c|c|c|c|c|c|c|c|c|c|}
\hline & $\begin{array}{l}\text { Kurumda } \\
\text { ki hizmet } \\
\text { süresi }\end{array}$ & n & $\overline{\mathbf{x}}$ & $\begin{array}{l}\text { Standart } \\
\text { Sapma }\end{array}$ & $\begin{array}{l}\text { Varyans } \\
\text { Kaynağı }\end{array}$ & $\begin{array}{l}\text { Kareler } \\
\text { Toplamı }\end{array}$ & df & $\begin{array}{c}\text { Karel } \\
\text { er } \\
\text { Ortal } \\
\text { aması }\end{array}$ & $\mathbf{F}$ & p & $\begin{array}{l}\text { Farkın } \\
\text { Kaynağı }\end{array}$ \\
\hline \multirow{4}{*}{ 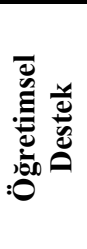 } & $1-3$ yil & 80 & 3,9514 & ,52618 & $\begin{array}{l}\text { Gruplarara } \\
\text { s1 }\end{array}$ & 2,875 & 2 & $\begin{array}{c}1,43 \\
8\end{array}$ & $\begin{array}{c}4,64 \\
5\end{array}$ & $\begin{array}{c}011 \\
*\end{array}$ & $\begin{array}{l}\text { (7 ve üstü } \\
\text { yıl)-(4-6 }\end{array}$ \\
\hline & 4-6 yil & 82 & 3,7873 & ,53535 & Gruplariçi & 66,547 & 215 & ,310 & & & y1l)* \\
\hline & $\begin{array}{l}7 \text { ve üstü } \\
\text { vıl }\end{array}$ & 56 & 4,0754 & ,62464 & Toplam & 69,422 & 217 & & & & \\
\hline & Toplam & 218 & 3,9215 & ,56561 & & & & & & & \\
\hline \multirow{4}{*}{ 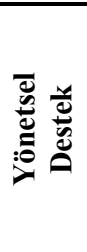 } & $1-3$ yil & 80 & 3,8875 & 63263 & $\begin{array}{l}\text { Gruplarara } \\
\text { si }\end{array}$ & 1,333 & 2 & ,666 & $\begin{array}{c}1,62 \\
0\end{array}$ & ,200 & - \\
\hline & 4-6 yil & 82 & 3,7453 & ,63180 & Gruplariçi & 88,426 & 215 & ,411 & & & \\
\hline & $\begin{array}{l}7 \text { ve üstü } \\
\text { yıl }\end{array}$ & 56 & 3,9266 & 66710 & Toplam & 89,759 & 217 & & & & \\
\hline & Toplam & 218 & 3,8440 & ,64315 & & & & & & & \\
\hline \multirow{4}{*}{$\frac{\frac{e}{\pi}}{\frac{\pi}{2}}$} & $1-3$ yil & 80 & 3,8011 & ,70731 & $\begin{array}{l}\text { Gruplarara } \\
\text { si }\end{array}$ & 1,314 & 2 & ,657 & $\begin{array}{c}1,31 \\
1\end{array}$ & ,272 & - \\
\hline & 4-6 yll & 82 & 3,7251 & ,64298 & Gruplariçi & 107,750 & 215 & ,501 & & & \\
\hline & $\begin{array}{l}7 \text { ve üstü } \\
\text { yıl }\end{array}$ & 56 & 3,9237 & ,79476 & Toplam & 109,064 & 217 & & & & \\
\hline & Toplam & 218 & 3,8040 & ,70894 & & & & & & & \\
\hline \multirow{4}{*}{ 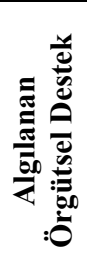 } & & 80 & 3,8746 & ,57620 & $\begin{array}{l}\text { Gruplarara } \\
\text { S1 }\end{array}$ & 1,685 & 2 & ,843 & $\begin{array}{c}2,40 \\
8\end{array}$ &, 092 & - \\
\hline & 4-6 yıl & 82 & 3,7506 & ,55000 & Gruplariçi & 75,226 & 215 & ,350 & & & \\
\hline & $\begin{array}{l}7 \text { ve üstü } \\
\text { yıl }\end{array}$ & 56 & 3,9717 & 66735 & Toplam & 76,911 & 217 & & & & \\
\hline & Toplam & 218 & 3,8529 & ,59534 & & & & & & & \\
\hline
\end{tabular}

$(p<.05)$

Tablo 12'ye göre araştırmaya katılan öğretmenlerin algıladıkları örgütsel destek düzeyleri ile görev yaptıkları okuldaki hizmet süresi değişkeni arasındaki farkı belirlemek amacıyla yapılan varyans analizi sonucunda, "öğretimsel destek" alt boyutu $\left(F_{(2,215)}=4,645 ; p<.05\right)$ ile görev yaptığ kurumdaki hizmet süresi arasında istatistiksel açıdan anlamlı bir farklılık olduğu görülmüştür. Farkın hangi gruplar arasında bulunduğunu belirlemek amaciyla post hoc testlerinden biri olan Tukey testinden yararlanılmıştır. Buna göre "öğretimsel destek" alt boyutunda 7 ve üstü yıl görev süresi olan öğretmenlerin $(\overline{\boldsymbol{x}}=4.0754)$, 4-6 yıl görev süresi olan öğretmenlere $(\overline{\boldsymbol{x}}=3.7873)$ göre daha fazla örgütsel destek algısına sahip oldukları belirlenmiştir.Araştırmaya katılan öğretmenlerin kendini sabote etme eğilimlerinin branş değişkenine göre istatistiksel olarak anlamlı farklılıklar olup olmadığını belirlemek amacıyla yapılan Tek Yönlü Varyans (ANOVA) analizi sonucunda elde edilen bulgular Tablo 13'te verilmektedir.

Tablo 13: Öğretmenlerin kendini sabote etme düzeyinin branş değişkenine göre incelenmesi

\begin{tabular}{|c|c|c|c|c|c|c|c|c|c|c|c|}
\hline & Branş & $\mathbf{n}$ & $\overline{\mathbf{x}}$ & $\begin{array}{l}\text { Standar } \\
\text { t Sapma }\end{array}$ & $\begin{array}{l}\text { Varyans } \\
\text { Kaynağı }\end{array}$ & $\begin{array}{l}\text { Kareler } \\
\text { Toplamı }\end{array}$ & df & $\begin{array}{l}\text { Kareler } \\
\text { Ortalam } \\
\text { ası }\end{array}$ & $\mathbf{F}$ & $\mathbf{p}$ & $\begin{array}{l}\text { Far } \\
\mathbf{k}\end{array}$ \\
\hline \multirow{9}{*}{ 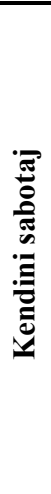 } & Okul öncesi & 14 & 2,6714 &, 53070 & Gruplararası & 1,391 & 7 & , 199 &, 875 &, 527 & - \\
\hline & Sınıf Öğretmeni & 33 & 2,7794 &, 57333 & Gruplariçi & 47,701 & 210 & ,227 & & & \\
\hline & Türkçe/Edebiyat & 23 & 2,9670 & ,49325 & Toplam & 49,092 & 217 & & & & \\
\hline & $\begin{array}{l}\text { Matematik/ Fen } \\
\text { Bilimleri }\end{array}$ & 42 & 2,7752 & ,47435 & & & & & & & \\
\hline & Sosyal Bilimler & 40 & 2,7970 & ,46756 & & & & & & & \\
\hline & Yabancı Dil & 17 & 2,6424 &, 35622 & & & & & & & \\
\hline & $\begin{array}{l}\text { Psikolojik } \\
\text { Danısman }\end{array}$ & 16 & 2,8150 & ,42979 & & & & & & & \\
\hline & Sanat/ Spor & 33 & 2,7345 & ,41891 & & & & & & & \\
\hline & Toplam & 218 & 2,7798 & ,47564 & & & & & & & \\
\hline
\end{tabular}


Tablo 13'te görüldüğü gibi araştırmaya katılan öğretmenlerin kendini sabotaj eğilimleri ile branş arasındaki farkı belirlemek amacıyla yapılan varyans analizi sonucunda, öğretmenlerin kendini sabote etmeleri ile branş arasında istatistiksel olarak anlamlı bir farklılık olmadığı görülmüştür $\left(F_{(7,210)}=, 875 ; p>\right.$ .05). Araştırmaya katılan öğretmenlerin algıladıkları örgütsel destek düzeylerinin branş değişkenine göre istatistiksel olarak farklılaşıp farklılaşmadığını belirlemek amacıyla yapılan Tek Yönlü Varyans (ANOVA) analizi sonucunda elde edilen bulgular Tablo 14'te verilmektedir.

Tablo 14: Öğretmenlerin algıladıkları örgütsel destek düzeyinin branş değişkenine göre incelenmesi

\begin{tabular}{|c|c|c|c|c|c|c|c|c|c|c|c|}
\hline & Branş & $\mathrm{n}$ & $\overline{\mathbf{x}}$ & $\begin{array}{l}\text { Standart } \\
\text { Sapma }\end{array}$ & $\begin{array}{l}\text { Varyans } \\
\text { Kaynağı }\end{array}$ & $\begin{array}{l}\text { Kareler } \\
\text { Toplamı }\end{array}$ & df & $\begin{array}{c}\text { Kareler } \\
\text { Ortalam } \\
\text { ası }\end{array}$ & $\mathbf{F}$ & p & $\underset{\mathbf{k}}{\operatorname{Far}}$ \\
\hline \multirow{9}{*}{ 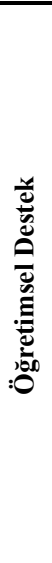 } & Okul öncesi & 14 & 3,8889 & ,81998 & $\begin{array}{l}\text { Gruplararas } \\
1\end{array}$ & 4,350 & 7 & ,621 & 2,005 &, 056 & - \\
\hline & Sınıf Öğretmeni & 33 & 3,8552 & ,55241 & Gruplariçi & 65,073 & 210 & ,310 & & & \\
\hline & $\begin{array}{l}\text { Türkçe/ } \\
\text { Edebiyat }\end{array}$ & 23 & 3,8647 &, 59831 & Toplam & 69,422 & 217 & & & & \\
\hline & $\begin{array}{l}\text { Matematik/ Fen } \\
\text { Bilimleri }\end{array}$ & 42 & 3,7725 & ,57967 & & & & & & & \\
\hline & Sosyal Bilimler & 40 & 4,1028 & ,51406 & & & & & & & \\
\hline & Yabancı Dil & 17 & 4,2222 & ,52411 & & & & & & & \\
\hline & $\begin{array}{l}\text { Psikolojik } \\
\text { Danışman }\end{array}$ & 16 & 3,7778 & 50998 & & & & & & & \\
\hline & Sanat/ Spor & 33 & 3,9259 & ,44415 & & & & & & & \\
\hline & Toplam & 218 & 3,9215 & ,56561 & & & & & & & \\
\hline \multirow{9}{*}{ 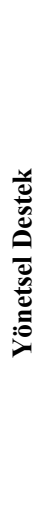 } & Okul öncesi & 14 & 3,7619 & ,84266 & $\begin{array}{l}\text { Gruplararas } \\
1\end{array}$ & 2,401 & 7 & ,343 &, 825 & 5,568 & - \\
\hline & Sınıf Öğretmeni & 33 & 3,7104 & ,72005 & Gruplariçi & 87,358 & 210 & ,416 & & & \\
\hline & $\begin{array}{l}\text { Türkçe/ } \\
\text { Edebiyat }\end{array}$ & 23 & 3,8116 & 62624 & Toplam & 89,759 & 217 & & & & \\
\hline & $\begin{array}{l}\text { Matematik/ Fen } \\
\text { Bilimleri }\end{array}$ & 42 & 3,7778 & ,66892 & & & & & & & \\
\hline & Sosyal Bilimler & 40 & 3,9722 & ,56921 & & & & & & & \\
\hline & Yabancı Dil & 17 & 4,0196 &, 55030 & & & & & & & \\
\hline & $\begin{array}{l}\text { Psikolojik } \\
\text { Danışman }\end{array}$ & 16 & 3,7500 & ,66233 & & & & & & & \\
\hline & Sanat/ Spor & 33 & 3,9192 &, 57284 & & & & & & & \\
\hline & Toplam & 218 & 3,8440 & 64315 & & & & & & & \\
\hline \multirow{9}{*}{$\frac{\frac{\omega}{\pi}}{\frac{\pi}{2}}$} & Okul öncesi & 14 & 3,8831 & ,98264 & $\begin{array}{l}\text { Gruplararas } \\
1\end{array}$ & 4,050 & 7 & ,579 & 1,157 & 329 & - \\
\hline & Sınıf Öğretmeni & 33 & 3,7603 & ,77099 & Gruplariçi & 105,013 & 210 &, 500 & & & \\
\hline & $\begin{array}{l}\text { Türkçe/ } \\
\text { Edebiyat }\end{array}$ & 23 & 3,7036 &, 73611 & Toplam & 109,064 & 217 & & & & \\
\hline & $\begin{array}{l}\text { Matematik/ Fen } \\
\text { Bilimleri }\end{array}$ & 42 & 3,6407 & ,78664 & & & & & & & \\
\hline & Sosyal Bilimler & 40 & 3,9614 & 60928 & & & & & & & \\
\hline & Yabancı Dil & 17 & 4,0160 & ,64702 & & & & & & & \\
\hline & $\begin{array}{l}\text { Psikolojik } \\
\text { Danışman }\end{array}$ & 16 & 3,6136 & ,68232 & & & & & & & \\
\hline & Sanat/ Spor & 33 & 3,8843 & ,49962 & & & & & & & \\
\hline & Toplam & 218 & 3,8040 & ,70894 & & & & & & & \\
\hline \multirow{7}{*}{ 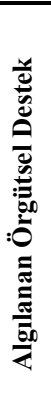 } & Okul öncesi & 14 & 3,8473 & ,84916 & Gruplararas & 3,297 & 7 & ,471 & 1,344 & 231 & - \\
\hline & Sınıf Öğretmeni & 33 & 3,7743 & ,64512 & Gruplariçi & 73,614 & 210 & ,351 & & & \\
\hline & $\begin{array}{l}\text { Türkçe/ } \\
\text { Edebiyat }\end{array}$ & 23 & 3,7871 & ,60272 & Toplam & 76,911 & 217 & & & & \\
\hline & $\begin{array}{l}\text { Matematik/ Fen } \\
\text { Bilimleri }\end{array}$ & 42 & 3,7241 & ,64241 & & & & & & & \\
\hline & Sosyal Bilimler & 40 & 4,0086 & ,50224 & & & & & & & \\
\hline & Yabancı Dil & 17 & 4,0811 &, 53656 & & & & & & & \\
\hline & $\begin{array}{l}\text { Psikolojik } \\
\text { Danışman }\end{array}$ & 16 & 3,7069 &, 56352 & & & & & & & \\
\hline
\end{tabular}




$\begin{array}{lccc}\text { Sanat/ Spor } & 33 & 3,9080 & , 46108 \\ \text { Toplam } & 218 & 3,8529 & , 59534\end{array}$

$(p<.05)$

Tablo 14'e göre araştırmaya katılan öğretmenlerin algıladıkları örgütsel destek düzeyleri ile branş değişkeni arasındaki farkı belirlemek amacıyla yapılan varyans analizi sonucunda, "öğretimsel destek" alt boyutu, $\left(F_{(7,210)}=2,005 ; p<.05\right)$, "yönetsel destek" alt boyutu $\left(F_{(7,210)}=, 825 ; p<.05\right)$, "adalet" alt boyutu $\left(F_{(7,210)}=1,157 ; p<.05\right)$ ve toplam algılanan örgütsel destek $\left(F_{(7,210)}=1,344 ; p<.05\right)$ ile branş arasında istatistiksel açıdan anlamlı bir farklılık olmadığı görülmüştür.

\section{Kendini Sabotaj ve Algılanan Örgütsel Destek Arasındaki Korelasyon}

Öğretmenlerin kendini sabote etme düzeyi ile algıladıkları örgütsel destek düzeyi arasındaki doğrusal ilişkinin gücü ve yönü Pearson Momentler Çarpımı Korelasyon Katsayısı ile test edilmiştir. Öğretmenlerin kendini sabote etme düzeyi ile algıladıkları örgütsel destek düzeyi arasındaki korelasyon Tablo 17 ' de verilmektedir.

Tablo 15 : Öğretmenlerin kendini sabote etme düzeyi ile algıladıkları örgütsel destek düzeyi arasındaki ilişkiye yönelik pearson momentler çarpımı korelasyon tablosu

\begin{tabular}{|c|c|c|c|c|c|}
\hline & 1 & 2 & 3 & 4 & 5 \\
\hline 1 KENDİNİ SABOTAJ & - & & & & \\
\hline 2 ALGILANAN ÖRGÜTSEL DESTEK &,$- 243^{*}$ & - & & & \\
\hline 3 Öğretimsel Destek Alt Boyutu &,$- 325^{* *}$ &, $885^{* *}$ & _ & & \\
\hline 4 Yönetsel Destek Alt Boyutu &,- 194 &, $928^{* *}$ &, $755^{* *}$ & _- & \\
\hline 5 Adalet Alt Boyutu &,$- 160^{*}$ &, $958^{* *}$ &, $757^{* *}$ &, $846^{* *}$ & - \\
\hline
\end{tabular}

Tablo 15'de görüldüğg̈ gibi araştırmaya katılan öğretmenlerin kendini sabote etme düzeyi ile algıladıkları örgütsel destek düzeyi arasında 0,05 anlamlılık düzeyinde negatif yönde düşük düzeyde ilişki $(r=-, 243 ; n=218 ; p=, 002)$ olduğu tespit edilmiştir. Buna göre katılımcı öğretmenlerin algıladıkları örgütsel destek düzeyi arttıkça kendini sabote etme eğilimlerinin azaldığı söylenebilir. Öğretmenlerin kendini sabote etme düzeyi ile öğretimsel destek alt boyutu arasında 0,01 anlamlılık düzeyinde negatif yönde orta düzeyde ilişki olduğu tespit edilmiştir $(r=-, 325 ; n=218 ; p=, 001)$. Buna göre katılımcıların öğretimsel destek düzeyi azaldıkça kendini sabote etme eğilimlerinin arttığı söylenebilir. Katılımcı öğretmenlerin kendini sabote etme düzeyi ile adalet alt boyutu arasında 0,05 anlamlılık düzeyinde negatif yönde düşük düzeyde ilişki olduğu görülmektedir ( $r=-, 160 ; n=218 ; p=, 018)$. Bu bulguya göre ise katılımcıların algıladıkları adalet düzeyi azaldıkça kendini sabote etme eğilimlerinin arttı̆̆ söylenebilir.

\section{Algılanan Örgütsel Desteğin Kendini Sabote Etme Davranışını Yordamasına İliş̧kin Regresyon Analizi}

Öğretmenlerin algıladıkları örgütsel desteğin kendini sabote etme düzeyini yordama gücünü belirlemek amacıyla yapılan doğrusal regresyon analizi sonuçları Tablo 18' de verilmektedir.

Tablo 16: Öğretmenlerin algıladıkları örgütsel desteğin, kendini sabote etme düzeyini yordamasına ilişkin regresyon analizi sonuçları

\begin{tabular}{|c|c|c|c|c|c|c|c|c|}
\hline & Yord & Değişl & Kendin & otaj) & & & & \\
\hline Yordayıcı Değişken & B & SE & B & $\mathbf{t}$ & $\mathbf{R}$ & $\mathbf{R}^{2}$ & $\mathbf{F}$ & p \\
\hline $\begin{array}{l}\text { ALGILANAN } \\
\text { DESTEK }\end{array}$ &,- 164 &, 068 &,- 243 & $-2,412$ &, $243^{*}$ &, 059 & 5,816 &, 002 \\
\hline Öğretimsel Destek Alt Boyutu &,- 218 & 066 &,- 325 & $-3,312$ &, $325^{* *}$ &, 106 & 10,972 & ,001 \\
\hline Yönetsel Destek Alt Boyutu &,- 124 &, 065 &,- 194 & $-1,193$ &, 194 & 037 & 3,621 &, 060 \\
\hline Adalet Alt Boyutu &,- 107 & 045 &,- 160 & $-2,380$ & $160^{*}$ & 026 & 5,666 & 018 \\
\hline
\end{tabular}

$* * P<.01 \quad * p<.05 \quad N=218$ 
Tablo 16'de görüldüğü gibi katılımcı öğretmenlerin algıladıkları örgütsel desteğin, kendini sabote etme eğilimlerini yordama gücünü belirlemek amacıyla yapılan regresyon analizi sonucunda, algılanan örgütsel destek ile öğretimsel destek ve adalet boyutunun kendini sabtajın yordayıcısı olduğu sonucuna ulaşılmıştır. Öğretimsel destek alt boyutu kendini sabotajın yaklaşık \% 11'ini, yönetsel destek alt boyutu kendini sabotajın \% 4'ünü, adalet alt boyutu kendini sabotajın \% 3'ünü açıklamaktadır. Dolayısıyla öğretmenlerin örgütsel destek algısının, kendini sabotajdaki varyansın \% 6'sını açıkladığı görülmektedir. Standardize edilmiş regresyon katsayılarının anlamlılığına ilişkin $t$ testi sonuçları incelendiğinde, öğretmenlerin algılanan örgütsel destek düzeylerinin kendini sabotajın anlamlı bir yordayıcısı olduğu belirlenmiştir.

\section{TARTIŞMA ve SONUÇ}

Çalışma kapsamında öğretmenlerin kendini sabote etme eğilimleri ile algıladıkları örgütsel destek arasındaki ilişsi incelenmiştir. Ayrıca katılımcı öğretmenlerin kendini sabotaj düzeylerinin cinsiyet, medeni durum, eğitim durumu, yaş, okul türü, kıdem, kurumdaki hizmet süresi, branş ve ödül sayısı gibi demografik değişkenlere göre farklılaşıp farklılaşmadığı incelenmiştir.

Araştırma sonucunda, öğretmenlerin kendini sabote etme eğilimlerinin düşük düzeyde (kısmen katılıyorum) olduğu belirlenmiştir. Bu bulgu; Akça (2012), Anlı (2011), Gündoğdu (2013), Büyükgöze ve Gün (2015), Mamaril, Usher ve Coyle (2013) 'un araştırma bulgularıyla benzerlik gösterdiği tespit edilmiştir. Kendini sabote etme eğilimi gösteren bireylerin genellikle olumsuz kişilik özelliklerine sahip oldukları, bu davranışı bilinçli olarak sergiledikleri, bu durumun bireyin hem kendisine hem de çalıştığı örgüte zarar verebileceği düşünülürse, toplumun geleceğini şekillendiren öğretmenlerin düşük düzeyde sabotaja sahip olmalarının olumlu bir sonuç olduğu söylenebilir.

Araştırma sonucunda, öğretmenlerin algıladıkları örgütsel desteğin yüksek düzeyde (katılıyorum) olduğu belirlenmiştir. Farklı araştırmalar da bu bulguyu desteklemektedir (Derinbay, 2011; Köse, 2015). Akkoç, Çalışkan ve Turunç (2012), Büyükgöze ve Kavak (2017), Üren ve Çorbacioğlu (2012)'nun çalışmalarında da algılanan örgütsel desteğin orta düzeyde olduğu olduğu görülmüştür.

Katılımcı öğretmenlerinin kendini sabote etme düzeyi kategorik değişkenlerden cinsiyet, medeni durum, eğitim durumu, yaş, okul türü, kıdem, görev yaptığı kurumdaki hizmet süresi, branş ve ödül sayıs1 gibi demografik değişkenlere göre anlamlı bir farklılık göstermemektedir. Araştırmaya katılan öğretmenlerinin algıladıkları örgütsel destek düzeyi kategorik değişkenlerden cinsiyet, medeni durum, eğitim durumu, yaş, branş ve ödül sayısı gibi demografik değişkenlere göre anlamlı bir farklılık göstermezken, katılımcıların örgütsel destek algısının okul türü ve görev yaptığı kurumdaki hizmet süresine göre anlamlı olarak farklılaştığı görülmektedir.

Bu çalışmada araştırmaya katılan kadın ve erkek öğretmenlerin benzer düzeyde kendini sabote etme eğilimlerine sahip olduğu belirlenmiştir. Altıntaş (2016), Barnes (2004), Brozowski (1999), Büyükgöze ve Gün (2015), Coşar (2012), Cowan \& Ferrari (2002), Doebler, Schick, Beck \& Astor-Stetson (2000), Dorman \& Ferguson, 2004; Ferrari \& Tice (2000), Gündoğdu (2013), Kalyon ve diğerleri (2016), Kaya (2016), Kinnon \& Murray (2007), Kuczka \& Treasure (2005), Midgley ve diğerleri (1996), Sarıçalı (2014), Standage ve diğerleri (2007), Strube \& Roemmele (1985), Taş (2017), Tice (1991), Topkaya (2017), Üzbe (2013), Yalnız (2014) ve Zafer (2016)'in yaptıkları araştırmalarda da cinsiyet değişkenine göre kendini sabotaj düzeylerinin farklılaşmadığı tespit edilmiştir. Anlı (2011), Anlı ve diğerleri (2015), Berglas \& Jones (1978), Eblin (2009), Harris \& Snyder (1986), Hirt ve diğerleri (2003), Hobden (1997), Kimble ve diğerleri (1998), Lucas \& Lovaglia (2005), McCrea \& Hirt (2008), Midgley \& Urdan (1995), Rhodewalt \& Hill (1995), Urdan ve diğerleri (1998)'ın yaptıkları çalışmalarda erkeklerin kendini sabote etme düzeylerinin anlamlı olarak daha yüksek olduğu ortaya çıkmaktadır. Kadınların kendini sabote eğilimlerinin anlamlı olarak daha yüksek olduğuna ilişkin veriler Rhodewalt \& Davison (1986), Weary \& Williams (1990), Yavuzer (2015)' in çalışmalarında da yer almaktadır. Alan yazın incelendiğinde cinsiyet ile kendini sabotaj arasında farklı sonuçlar bulunmakla birlikte erkekler akademik yetenekleri, kadınlar ise sosyal yetenekleri ile ilgili görevlerde kendilerini sabote etmektedir (Abacı ve Akın, 2011; Dietrich, 1995; Meyer, 2000).

Araştırma sonucunda, kadın ve erkek öğretmenlerin örgütsel destek algısının benzer düzeyde olduğu belirlenmiştir. Algılanan örgütsel destek düzeyinin cinsiyet değişkenine göre farklılaşmadığı çalışmaların da olduğu tespit edilmiştir (Büyükgöze ve Kavak, 2017; Derinbay, 2011; Doğan, 2014; Eğriboyun, 2013; Erdaş, 2010; Kartal, Y irci ve Özdemir, 2015; Köse, 2015; Nartgün ve Kalay, 2014; Nayır, 2011; Taşkın, 2016; Yokuş, 2006; Yu ve Frenkel, 2013). Bununla birlikte, Nayır (2011), Yoon ve Lim 
(1999)'in çalışmalarında da erkeklerin algıladığı örgütsel desteğin kadınlara göre daha yüksek düzeyde olduğu tespit edilmiştir.

Araştırma sonuçları, evli ve bekar öğretmenlerin benzer düzeyde kendini sabote etme eğilimi gösterdiklerini ortaya koymuştur. Değişik araştırmalar da bu bulguyu desteklemektedir (Coşar, 2012; Büyükgöze ve Gün, 2015; Zafer, 2016).

Araştırma bulguları, evli ve bekar katılımcıların örgütsel desteğe ilişkin algılarının da benzer olduğunu göstermektedir. Bu bulgu ile paralellik gösteren çalışmalar olduğu da tespit edilmiştir (Köse, 2015; Nayır, 2011; Taşkın, 2016). Sosyal destek kuramına göre, örgütlerde çalışanların algıladıkları sosyal ve psikolojik desteğin, bireylerin tutum ve davranışları üzerinde olumlu etkisi olmaktadır. Bu nedenle, evli öğretmenlerin bekar öğretmenlere göre örgütsel destek algısının daha yüksek düzeyde olması ve bunun sonucu olarak da kendini sabote etme eğilimlerine daha az başvurmaları beklenilebilir.

$\mathrm{Bu}$ çalışmaya katılan lisans ve yüksek lisans mezunu öğretmenlerin kendini sabote etme eğilimlerinin benzer düzeyde olduğu sonucuna ulaşılmıştır. Farklı araştırmalarda lisans mezunları yüksek lisans mezunlarına göre kendini sabote etme boyutunda daha yüksek puan almışlardır (Kalyon, Dadandı ve Yazıc1, 2016). Kendini sabotaj düzeyi ile eğitim durumu arasında anlamlı fark bulunan çalışmaların da olduğu tespit edilmiştir (Civan, 2016).

Araştırma sonuçları, lisans ve yüksek lisans mezunu öğretmenlerin algıladıkları örgütsel desteğin benzer düzeyde olduğunu ortaya koymuştur. Literatür incelendiğinde bu bulguyu destekleyen nitelikte araştırmaların bulunduğu görülmektedir (Büyükgöze ve Kavak, 2017; Erdaş, 2010; Köse, 2015; Nartgün ve Kalay, 2014; Rhoades ve Eisenberger, 2002; Taşkın, 2016). Ancak lisansüstü eğitim gören çalışanların daha yüksek örgütsel destek algısına sahip olduğunu (Yoon \& Lim, 1999) ve lisans mezunu öğretmenlerin ön-lisans ile yüksek lisans mezunu öğretmenlere göre daha yüksek örgütsel destek algısına sahip olduğunu (Doğan, 2014; Eğriboyun, 2013) belirten çalışmalar da bulunmaktadır.

Araştırmaya katılan öğretmenlerin yaş değişkenine göre kendini sabote etme davranışlarının benzer düzeyde olduğu görülmüştür. Bu bulguyu bazı çalışmalar da destekler niteliktedir (Civan, 2016; Coşar, 2012; Taş, 2017). Ancak yaş arttıkça kendini sabote etme eğiliminin azaldığı çalışmaların da olduğu tespit edilmiştir (Topkaya, 2017).

$\mathrm{Bu}$ çalı̧̧mada, katılımcı öğretmenlerin yaşlarına göre algıladıkları örgütsel desteğin benzer düzeyde olduğu sonucuna ulaşılmıştır. Bu bulgu ile paralellik gösteren çalışmaların da bulunduğu tespit edilmiştir (Eğriboyun, 2013; Taşkın, 2016). Ancak 23-30 yaş aralığındaki öğretmenlerin, 39-46 yaş aralığındaki öğretmenlere göre daha fazla örgütsel d estek algısına sahip olduğunu gösteren çalışmalar da bulunmaktadır (Derinbay, 2011).

Katılımcı öğretmenlerin mesleki kıdemlerine ve bulundukları kurumda görev yapma sürelerine göre kendini sabote etme davranışlarını benzer düzeyde gösterdikleri görülmüştür. Aynı şekilde hizmet yılı ile kendini sabotaj arasında anlamlı fark bulunmayan, ancak kıdemi yüksek olanların kendini sabote eğilimlerinin daha yüksek olduğu çalışmaların olduğu da görülmüştür (Büyükgöze ve Gün, 2015).

Katılımcı öğretmenlerin örgütsel destek algılarının, mesleki kıdeme göre benzer düzeyde olduğu belirlenmiştir. Annamalai ve diğerleri (2010), Büyükgöze ve Kavak (2017), Bozkurt (2007), Eğriboyun (2013), Eisenberger ve diğerleri ( 2013), Köse (2015), Nartgün ve Kalay (2014), Nayır (2011), Rhoades ve Eisenberger (2002), Taşkın (2016), Yirci (2014), Kartal ve diğerleri (2015), Yu \& Frenkel (2013)'in araştırma sonuçları da bu bulguyu desteklemektedir. Doğan (2014), Köse (2015), Stinglhamber \& Vandenberghe (2003)'in çalışmaları çalışanların kıdemleri arttıkça örgütsel destek algısının azaldığını azaldığını göstermektedir. Bu ise, kıdem arttıkça çalışanların örgütten beklentilerinin arttı̆̆ 1 ya da farklı örgütsel destek ihtiyaçları ve beklentilerinin ortaya çıkabileceği şeklinde yorumlanabilir.

Bu çalışmada, araştırmaya katılan okul öğretmenlerin okul (ilkokul, ortaokul ve lise) türüne göre kendini sabote etme eğilimlerinin benzer düzeyde olduğu görülmüştür. Katılımc1 öğretmenlerin örgütsel destek algısının görev yaptıkları okul türüne göre anlamlı olarak farklılaştığı tespit edilmiştir. Buna göre ortaokul öğretmenlerinin, lise öğretmenlerine göre algıladıkları örgütsel desteğin daha fazla olduğu görülmüş̧ür. Ancak Büyükgöze ve Kavak (2017), Eğriboyun (2013), Kartal ve diğerleri (2015) nin çalışmalarında olduğu gibi öğretmenlerin örgütsel destek algısının okul türü değişkenine göre farklılaşmadığı da tespit edilmiştir. 
Araştırmaya katılan öğretmenlerin branşlarına göre kendini sabote etme eğilimlerinin farklılaşmadığı sonucuna ulaşılmıştır. Bu çalışmada, branşlarına göre öğretmenlerin algıladıkları örgütsel desteğin de benzer düzeyde olduğu sonucuna ulaşılmıştır. Öğretmenlerin branşı ile örgütsel destek algısı arasında fark bulunmayan çalışmalar da bu bulguyu destelemektedir (Derinbay, 2011; Eğriboyun, 2013; Köse, 2015). Ancak branş öğretmenlerinin, sınıf öğretmenlerine göre daha yüksek örgütsel destek algısına sahip olduğunu (Doğan, 2014) ve sayısal branştaki öğretmenlerin, sözel branştaki öğretmenlere göre daha yüksek örgütsel destek algısına sahip olduğunu (Kartal, Yirci ve Özdemir, 2015) gösteren çalışmalar da bulunmaktadır.

Öğretmenlerin kendini sabote etme düzeyinin öğretimsel destek alt boyutu ile orta düzeyde negatif yönde ilişskili olduğu, öğretimsel destek arttıkça kendini sabotajın azaldığı sonucuna ulaşılmıştır. Büyükgöze (2014), Luthans ve diğerleri (2008), Tian \& Xie (2010) çalışanların yüksek düzeyde örgütsel destek algısına sahip olmalarının psikolojik sermaye düzeylerinin artmasını, bu durumun ise çalışanların örgüte olumlu örgütsel davranışlarda bulunmasını ve çalışanların iş performanslarının artmasını sağlayacağını belirtmektedirler. Dolayısıyla öğretmenlerin algıladıkları öğretimsel desteğin artırılması, bilinçli bir şekilde gerçekleştirilen performans engelleyici bir davranış olan kendini sabotajın azaltılmasını sağlayabilir. Öğretmenlerin kendi iş alanları konusunda okul yönetimi tarafından desteklenmeleri, öğretmenlerin üst düzey performans sergilemelerini sağlarken bu durum öğretmenlerin kendini sabote etme davranış1 göstermelerini de engelleyebilmektedir.

Öğretmenlerin kendini sabote etme düzeyinin adalet alt boyutu ile düşük düzeyde negatif yönde ilişkili olduğu, adalet desteği arttıkça kendini sabotajın azaldığ algıladıkları örgütsel desteğin artması okullarına ilişkin duygusal bağl11ılarını artırdığını (Eğriboyun,2014; Uzun, 2018); öğretmenlerin okul içinde desteklendiklerini, yaptıkları çabanın fark edildiğini ve sorunlarının dikkate alındığını görmeleri örgütsel vatandaşlık davranışlarını artırdığını (Demir, 2015; Nadim, Hassan, Ab-bas ve Naveed, 2016; Uzun, 2018); öğretmenlerin algıladığı örgütsel desteğin artmas1, okullarına ilişkin örgütsel güven duygusunu da artırdığını (Celep ve Yılmaztürk, 2012; Kara, Güneş ve Aydoğan, 2015; Taştan ve Yalçın, 2010; Uzun, 2018) ortaya koymaktadır. Dolayısıyla okul yönetiminin insan kaynağı uygulamalarındaki adaletli politikası, eşit ve adil ödüllendirme sistemi, yönetimin çalışanlarının katkısının farkında olması, güven duygusu ile çalışanlara varlığını hissettirmesi öğretmenlerin algıladıkları örgütsel destek düzeyini artırmaktadır. Okul yönetiminin adaletli olan destek algısı da öğretmenlerde mutluluğu, morali, motivasyonu, duygusal bağlılığ (Eğriboyun, 2013; Nayır, 2011; Özdevecioğlu, 2003; Rhoades \& Eisenberger, 2002); öğretmenlerde kendini sabote etme davranışlarını azaltmak, olumlu duygu, tutum ve davranışlar oluşturmak isteyen yöneticilerin özellikle adaletli davranmaya önem vermeleri gerekmektedir.

Bu çalışmada, öğretimsel destek alt boyutunun kendini sabotajın \% 11'ini, yönetsel destek alt boyutunun kendini sabotajın \% 4'ünü, adalet alt boyutunun kendini sabotajın \% 3'ünü açıkladığı sonucuna ulaşılmıştır. Dolayısıyla öğretmenlerin örgütsel destek algısının, kendini sabotajdaki varyansın \% 6'sını açıkladığı, kendin sabotajın güçlü olmasa da önemli ve istatistiki açıdan anlamlı bir rolünün olduğu görülmektedir. Algılanan örgütsel destek, kendini sabotajın belli bir kısmını yordadığı için açıklanamayan varyansın farklı değişkenlerle (örgüt kültürü, örgüt iklimi, liderlik, motivasyon, vb.) araştırılması alana katk1 sağlayabilir.

\section{1. Öneriler}

$\mathrm{Bu}$ çalışmanın sonuçlarına göre öğretmenlerin örgütsel destek algıları arttıkça kendini sabotaj düzeylerinin azaldığı söylenilebilir. Bu kapsamda okul yöneticileri tarafindan öğretmenlerin örgütsel destek algılarını arttırıcı destek ve önlemlerin uygulamaya konulması önerilebilir.

Öğretim liderliği; yapıyı kurmak, kendisi ve örgüt üyeleri arasındaki ilişkileri belirlemek, örgütün kalıplarını, kanallarını ve prosedürlerini koymak, arkadaşlık, güvenme, saygı ve içtenlik davranışlarını kapsar" (Bursalığlu, 2015). Okul yöneticilerinin öğretimsel liderlik davranışlarını sergilemesi, çalışanlarına desteklendiğini hissettirmesi, öğretmenlerin kendini sabote etme eğilimlerini azaltabilmektedir. Öğretmenlerin performanslarını açığa çıkartacak, başarı, gelişme ve ilerleme imkanları sağlayacak güdüleyici etkinlikler düzenlenebilir, öz yeterlilik düzeyleri artırılabilir. Öğretmenler için profesyonel destek verilerek, kaygı düzeyleri azaltılabilir ve benlikleri güçlendirilebilir. Kendini sabotajı önlemek için bilişsel ve davranışsal olarak öğretmenlerin güçlenmeleri sağlanabilir. Araştırma sonuçlarının, öğretmenlerin okul içindeki algı, tutum ve davranışlarının anlaşılmasında, performanslarının artırılmasında, okulun hedeflerine ulaşarak etkililiğinin ve verimliliğinin artırılmasında, eğitim-öğretim 
hizmetlerinde kalite ve başarının gerçekleştirilmesinde eğitim yöneticilerine katkılar sağlayacağı düşünülmektedir.

Gelecek araştırmalarda araştırma örnekleminin ya da çalışma grubunun genişletilerek farklı özelliklere sahip okullardaki öğretmenlerden toplanacak veriler ile de desteklenmesi sonuçların genellenebilirliğini artırabilir. Eğitim kurumlarında öğretmenlerin kendini sabote etme davranışı karma araştırma yöntemi kullanılarak daha derinlemesine incelenebilir. 


\section{KAYNAKLAR}

Abacı, R. ve Akın, A. (2011). Kendini Sabotaj: Insanoğlunun Sınırlı Doğasının Bir Sonucu. Ankara: Pegem Akademi. Akın, A. (2012).Kendini sabotaj ölçeği:Geçerlik ve güvenirlik çalışması.Eğitim ve Bilim Dergisi, (37), 164:176-187.

Akın, Ü. (2013). Akılcı duygusal davranışçı terapi odaklı psiko-eğitim programının kendini sabotaj üzerine etkisi. Yayınlanmamış doktora tezi. Sakarya Üniversitesi Eğitim Bilimleri Enstitüsü, Sakarya.

Akkoç, İ., Çalışkan, A. ve Turunç, Ö. (2012). Örgütlerde gelişim kültürü ve algılanan örgütsel desteğin iş tatmini ve iş performansına etkisi: Güvenin aracılık rolü. Yönetim ve Ekonomi Dergisi, 19(1), 105-135.

Anlı, G. (2011).Kendini sabotaj ile psikolojik iyi olma arasındaki ilişkinin çeşitli değişkenler açısından incelenmesi.Yayınlanmamış yüksek lisans tezi. Sakarya Üniversitesi Eğitim Bilimleri Enstitüsü, Sakarya.

Anlı, G., Akın, A., Şar, A.H. ve Eker, H.(2015). Kendini sabotaj ile psikolojik iyi olma arasındaki ilişkinin çeşitli değişkenler açısından incelenmesi. Electronic Journal of Social Sciences, 14:160-172.

Annamalai, T., Abdullah, A. G. K. , Alazidiyeen, N. J. (2010). The Mediating Effects of POS On The Relationship Between Organizational Justice, Trust And Performance Appraisal in Malaysian Secondary Schools, European Journal of Social Sciences, 13 (4), 623-632.

Barnes, B. (2004). Gender differences in use of anxiety as a self handicapping strategy on effort and performance. Unpublished doctoral dissertation, University of Fielding Graduate, USA.

Berglas, S. \& Jones, E.E. (1978). Drug choice as a self-handicapping strategy in response to non-contingent success. Journal of Personality and Social Psychology, 36 (4), 405-417.

Bozkurt, F. (2007). Denizcilik sektöründe çalışan gemi adamlarının demografik özellikleri ile örgütsel bă̆lllık, örgütsel vatandaşlı davranışı ve algllanan örgütsel destek düzeyi arasındaki ilişkiyi incelemeye yönelik bir araştırma. Yayımlanmamış Yüksek Lisans Tezi. Celal Bayar Üniversitesi Sosyal Bilimler Enstitüsü, Manisa.

Brzozowski, D. M. N. (1999). Self-handicapping: Gender differences, perception of classroom goal structure, and the presence or absence of a learning disability. Unpublished Master dissertation, University of Kean, USA.

Bursalığlu, Z. (2015). Okul yönetiminde yeni yapı ve davranış. Ankara: Pegem Akademi.

Büyükgöze, H. (2014). Lise öğretmenlerinin görüşlerine göre algllanan örgütsel destek ve psikolojik sermaye ilişkisi. Yayınlanmamış yüksek lisans tezi. Hacettepe Üniversitesi Eğitim Bilimleri Enstitüsü, Ankara.

Büyükgöze, H. ve Gün, F. (2015).Araştırma Görevlilerinin Kendini Sabotaj Eğilimlerinin İncelenmesi. Hitit Üniversitesi Sosyal Bilimler Enstitüsü Dergisi, (8),2:689-704.

Büyükgöze, H. ve Kavak, Y. (2017). Algılanan örgütsel destek ve pozitif psikolojik sermaye ilişkisi: Lise öğretmenleri örnekleminde bir inceleme. Kuram ve Uygulamada Eğitim Yönetimi, 23(1), 1-32.

Celep, C., ve Yilmazturk, O. E. (2012). The relationship among organiza-tional trust, multidimensional organizational commitment and perceived organizational support in educational organiza-tions. Procedia-Social and Behavioral Sciences, 46, 5763-5776.

Civan, S. (2016). Eylemlilik ve kendini sabotaj arasındaki ilişkinin çeşitli değişkenler açısından incelenmesi. Yayınlanmamış yüksek lisans tezi. Sakarya Üniversitesi Eğitim Bilimleri Enstitüsü, Sakarya.

Coşar, S.(2012). Çalışanların tükenmişlik düzeyleri ile kendini engelleme düzeyleri arasındaki ilişkinin incelenmesi. Yayınlanmamış yüksek lisans tezi. Maltepe Üniversitesi Sosyal Bilimler Enstitüsü, İstanbul.

Cowan, S. E. \& Ferrari, J. R. (2002). “Am I for real?” Predicting impostor tedencies from self-handicapping and affective components. Social Behavior and Personality, 30(2), 119-126.

Derinbay, D. (2011).İlkögrretim okullarında görev yapan öğretmenlerin örgütsel destek düzeyleri. Yayınlanmamış yüksek lisans tezi.Pamukkale Üniversitesi, Eğitim Bilimleri Enstitüsü, Denizli.

Demir, K. (2015). The effect of organizational justice and perceived organ-izational support on organizational citizenship behaviors: The me-diating role of organizational identification. Eurasian Journal of Ed-ucational Research, 60, 131- 148 .

Dietrich, D. (1995). Gender differences in self-handicapping: Regardless of academic or social competence implications. Social Behavior and Personality, 23, 402-410.

Doebler, L.P., Schick, C., Beck, B. \& Astor-Stetson, E. (2000). Ego protection: The effectsof gender and perfectionism on acquired and claimed self-handicapping and self-esteem. College Student Journal, 34, 524-537. 
Doğan, S. (2014). Illkokullarda görev yapan öğretmenlerin örgütsel destek algısı (Polatll ilçesi örneği). Yayınlanmamış yüksek lisans tezi. Hacettepe Üniversitesi, Eğitim Bilimleri Enstitüsü, Ankara.

Dorman, J. P. \& Ferguson, J. M. (2004). Associations between students'perceptions of mathematics classroom environment and self-handicapping in australian and canadian high schools. McGill Journal of Education, 39(1), 69 .

Eblin, J. J. (2009). Gender differences in claimed self-handicapping: The role of group status and effort prime (Unpublished senior honors thesis). The Ohio State University: Ohio, USA.

Eğriboyun, D. (2013). Ortä̈ğretim okullarında görev yapan yönetici ve öğretmenlerin örgütsel güven, örgütsel destek ve örgütsel bağlllıkları arasındaki ilişsi (Bolu ili örneği). Yayınlanmamış doktora tezi. Abant İzzet Baysal Üniversitesi, Eğitim Bilimleri Enstitüsü, Bolu.

Eğriboyun, D. (2014). Ortaöğretim okullarında görev yapan yönetici ve öğretmenlerin örgütsel destek ve örgütsel bağl11ıkları arasındaki ilişki. Gümüşhane Üniversitesi Sosyal Bilimler Elektronik Dergisi, 9, 25-52.

Eisenberger, R., Huntington, R., Hutchison, S. ve Sowa, D. (1986). Perceived Organizational Support. Journal of Applied Psycology, 7, 500-507.

Eisenberger, R., Shoss, M. K., Karagonlar, G., Gonzalez-Morales, M. G., Wickham, R. E., \& Buffardi, L. C. (2013). The supervisor POS-LMX-subordinate POS chain: Moderation by reciprocation wariness and supervisor's organizational embodiment. Journal of Organizational Behavior, 35(5), 635-656.

Erdaş, K. D. (2010). Lider-üye mübadelesi, algllanan örgütsel destek ve öz-denetim kişilik özelliğinin örgütsel vatandaşlık davranışları üzerindeki etkileri. Yayımlanmamış yüksek lisans tezi. Hacettepe Üniversitesi, Ankara.

Ferrari, J.R. \& Tice, D.M. (2000). Procrastination as a self-handicap fo men and women: A task-avoidance strategy in a laboratory setting. Journal of Research in Personality, 34, 73-83.

Gündoğdu, R. (2013). Investigation of self-handicapping tendenciesof teacher candidates according to demographic variables by controlling self-esteem scores. Turkish Studies-International Periodical For The Languages, Literature and History of Turkish or Turkic, 8/3:263-277.

Harris, R. N., \& Snyder, C. R. (1986). The role of uncertain self-esteem in selfhandicapping. Journal of Personality and Social Psychology, 51, 451-458.

Hirt, E. R., McCrea, S. M., \& Boris, H. I. (2003). "I know you self-handicapped last exam": Gender differences in reactions to self-handicapping. Journal of Personality and Social Psychology, 84(1), 177-193.

Hobden, K. L. (1997). Behavioral versus claimed self-handicapping: Underlying motivations and attributions following failure (Unpublished doctoral dissertation). University of Toronto, Canada.

Kalyon, A., Dadandı, İ. ve Yazıcı, H.(2016). Kendini sabote etme eğilimi ile narsistik kişilik özellikleri, anksiyete duyarlılığı, sosyal destek ve akademik başarı arasındaki ilişki. Düşünen Adam Dergisi, 29, 237-246

Kara, S. B. K., Güneş, D. Z., ve Aydoğan, N. N. (2015). Perceived organi-zational support and organizational trust in primary schools. Journal of Human Sciences, 12(2), 385-393.

Karasar, N. (2017). Bilimsel araştırma yöntemi: Kavramlar, ilkeler, teknikler (32.Basım). Ankara: Nobel Yayıncılık.

Kartal, S.E., Yirci,R. ve Özdemir, T.Y. (2015). Öğretmenlerde algılanan örgütsel destek düzeyi ile yaşam memnuniyeti arasındaki ilişkinin incelenmesi. Dicle Üniversitesi Ziya Gökalp Eğitim Fakültesi Dergisi, 24: 477-504.

Kaya, F.(2016).Sınıf ögretmenliği öğrencilerinin başarı yönelimi, kendini engelleme davranışları ve demografik özelliklerinin okula yabancılaşmayı yordama düzeylerinin incelenmesi. Yayınlanmamış yüksek lisans tezi. Çukurova Üniversitesi Sosyal Bilimler Enstitüsü, Adana.

Kimble, C. E., Kimble, E. A., \& Croy, N. A. (1998). Development of self-handicapping tendencies. The Journal of Social Psychology, 138(4), 524-534.

Kinon, M. D. \& Murray, C. B. (2007). A Profile of the College Self-Handicapper. Under graduate Research Journal, $1,13-17$.

Kuczka, K.K. \& Treasure, D.C. (2005). Self-handicapping in competitive sport: Influence of the motivational climate, self-efficacy and perceived importance. Psychology of Sport and Exercise, 6 (5), 539-550.

Köse, A. (2015). İşe angaje olma ile örgütsel destek algısı ve örgüt iklimi arasındaki iliş̧ki (Kahramanmaraş ili örneği). Yayınlanmamış doktora tezi. Zirve Üniversitesi Kahramanmaraş Üniversitesi Sosyal Bilimler Enstitüsü, Gaziantep. 
Lucas, J.W. \& Lovaglia, M.J. (2005). Self-handicapping: Gender, race and status. Current Research in Social Psychology, 10(15), 234-249.

Luthans, F., Norman, S. M., Avolio, B. J., \& Avey, J. B. (2008). The mediating role of psychological capital in the supportive organizational climate-employee performance relationship. Journal of Organizational Behavior, 29, 219-238.

Mamaril, N.A., Usher, E.L., \& Coyle, B.A. (2013). Academic self-handicapping and self-efficacy as predictors of mathematics achievement of African American middle school students. P20 Motivation and Learning Lab, University of Kentucky, College of Education, Kentucky, USA.

Mccrea, S. M., \& Hirt, E. R. (2008). She works hard for the money: Valuing effort underlies gender differences in behavioral self-handicapping. Journal of Experimental and Social Psychology, 44(2), 292-311.

Meyer, C. (2000). Academic procrastination and self-handicapping: Gender differences in response to non-contingent feedback. Social Behavior and Personality, 15(5), 87-102.

Midgley, C. \& Urdan, T. (1995). Predictors of middle school students' use of self-handicapping strategies. Journal of Early Adolescence, 15, 389-411.

Midgley, C., Arunkumar, R. \& Urdan, T. (1996). If I don't do well tomorrow, there's a reason: Predictors of adolescents' use of self-handicapping strategies. Journal of Educational Psychology, 88, 423-434.

Metin, M. (2014). Kuramdan Uygulamaya Eğitimde Bilimsel Araştırma Yöntemleri. Ankara: Pegem Akademi Yayıncilik.

Nadim, M., Hassan, M. M., Abbas, S. ve Naveed, A. (2016). The role of organizational commitment and perceived organizational support in promoting organizational citizenship behavior. People: Inter-national Journal of Social Sciences, 2(3), 54-67.

Nartgün, Ş.S. ve Kalay, M. (2014). Öğretmenlerin örgütsel destek, örgütsel özdeşleşme ile örgütsel sinizm düzeylerine ilişkin görüşleri. Turkish Studies - International Periodical For The Languages, Literature and History of Turkish or Turkic Volume 9(2) Winter 2014, p. 1361-1376.

Nayır, F.(2011).İlköğretim okulu yöneticilerinin ögrretmenlere sağlanan örgütsel desteğe ilişkin görüşleri, ögretmenlerin örgütsel destek algısı ve örgütsel bă̆lllıkla ilişkisi.Yayınlanmamış doktora tezi.Ankara Üniversitesi, Eğitim Bilimleri Enstitüsü, Ankara.

Öğretmen Strateji Belgesi (2017-2023). Resmi Gazete: 09.06.2017/30091.

Öğretmenlik Mesleği Genel Yeterlilikleri. Tebliğler Dergisi: 13.12.2017/2590.

Özdevecioğlu, M. (2003). Algılanan örgütsel destek ile örgütsel bağlılık arasındaki ilişkilerin belirlenmesine yönelik bir araştırma. Dokuz Eylül Üniversitesi İktisadi ve İdari Bilimler Fakültesi Dergisi, 18 (2), 113-130.

Rhoades, L. \& Eisenberger, R. (2002). Perceived Organizational Support: A Review of the Literature. Journal of Applied Psychology, 87(4):698-714.

Rhodewalt, F. \& Davison, M. (1986). Claimed self-handicaps and the self-handicapper: The relation of reduction in intented effort to performance. Journal of Research in Personality, 25, 402-417.

Rhodewalt, F., \& Hill, K. (1995). Self-handicapping in the classroom: The effects of claimed self-handicaps on responses to academic failure. Basic and Applied Social Psychology, 16(4), 397-416.

Sarıçalı, M. (2014). Psikolojik danışman adaylarının kendini engelleme algılarının özgünlük düzeyleri ve aldıkları süpervizyon açısından incelenmesi. Yayınlanmamış yüksek lisans tezi. Anadolu Üniversitesi Eğitim Bilimleri Enstitüsü, Eskişehir.

Standage, M., Treasure, D.C., Hooper, K., \& Kuczka,K, (2007). Self-handicapping in school physical education: The influence of the motivational climate. British Journal of Educational Psychology, 77 (1), 81-99.

Stinglhamber, F., \& Vandenberghe, C. (2003). Organizations and supervisors as sources of support and targets of commitment: A longitudinal study. Journal of Organizational Behavior, 24, 251-270.

Strube, M.J. \& Roemmele, L.A. (1985). Self-enhancement, self-assessment and self-evaluative task choice. Journal of Personality and Social Psychology, 49, 981-993.

Taş, R.(2017). Üniversite öğrencilerinin romantik ilişkilerinde kişilerarası yetkinlik düzeylerinin kendini sabotaj eğilimine olan etkisinin incelenmesi. Yayınlanmamış yüksek lisans tezi. Erciyes Üniversitesi Sosyal Bilimler Enstitüsü, Kayseri.

Taşdan, M., ve Yalçın, T. (2010). İlköğretim okulu öğretmenlerinin algıladıkları sosyal destek ile örgütsel güven düzeyleri arasındaki ilişki düzeyi. Kuram ve Uygulamada Ĕgitim Bilimleri, 10(4), 2569-2620. 
Taşkın, S. (2016). Öğretmenlerin örgütsel destek ve örgütsel özdeşleşme düzeyleri ile insiyatif iklimi arasındaki ilişki. Yayınlanmamış yüksek lisans tezi. İzzet Baysal Üniversitesi Eğitim Bilimleri Enstitüsü, Bolu.

Tian, X. Z., \& Xie, J. Y. (2010). The influence of perceived organizational support on working behaviors of employees: Empirical research on mediating role of psychological capital. Nankai Business Review, 13, 23-29.

Tice, D.M. (1991). Esteem protection or enhancement? Self-handicapping motives and attributions differ by trait selfesteem. Journal of Personality and Social Psychology, 60 (5), 711-725.

Topkaya, N.(2017). Üniversite ögrencilerinde kendini sabotajın yordayıcısı olarak cinsiyet, yaş ve farklı mükemmeliyetçilik tarzları. Yayınlanmamış yüksek lisans tezi. Ondokuz Mayıs Üniversitesi Eğitim Bilimleri Enstitüsü, Samsun.

Urdan, T., Midgley, C., \& Anderman, E. (1998). The role of classroom goal structure in students' use of selfhandicapping strategies. American Educational Research Journal, 35, 101-122.

Uzun, T. (2018). Okullarda algılanan örgütsel destek, örgütsel güven, duygusal bağlılık ve örgütsel vatandaşlık davranışı arasındaki ilişki. Opus-Uluslararası Toplum Araştırmaları Dergisi, 8(15): 958-987.

Üren, S. G. ve Çorbacıŏ̆lu, S. (2012). Alg̈llanan örgütsel desteğin örgütsel bağlılığa etkisi: İmalat sektöründe faaliyet gösteren bir işletme örneği. Gazi Üniversitesi İktisadi ve İdari Bilimler Fakültesi Dergisi, 14(1), 29-52.

Üzar Özçetin,Y.S.ve Hiçdurmaz, D.(2016). Kendini sabote etme ve ruh sağlı̆̆ı üzerine etkisi. Psikiyatride Güncel Yaklaşımlar Dergisi, (8), 2:145-154.

Üzbe, N.(2013). Başarı hedef yönelimi, benlik saygısı ve akademik başarının kendini engellemeyi yordamadaki rolü. Yayınlanmamış yüksek lisans tezi. Gazi Üniversitesi Eğitim Bilimleri Enstitüsü, Ankara.

Weary, G. \& Williams, J.P. (1990). Depressive self-presentation: Beyond self handicapping. Journal of Personality and Social Psychology, 58(5), 892-898.

Yalnız, A. (2014). Algllanan anne baba tutumlarl, kendini sabotaj ve öz-yeterlik arasındaki ilişkinin incelenmesi. Yayınlanmamış yüksek lisans tezi. Sakarya Üniversitesi Eğitim Bilimleri Enstitüsü, Sakarya.

Yavuzer, Y. (2015). Investigating the relationship between selfhandicapping tendencies, self-esteem and cognitive distortions. Educational Sciences: Theory and Practice, 15:879-890.

Yirci, R. (2014). Devlet ve vaklf üniversitelerindeki öğretim elemanlarının algllanan örgütsel destek, örgütsel bă̆lllık düzeyleri ile yüksekögretimde özelleştirmeye ilişkin görüşlerinin karşılaştırılması. Yayımlanmamış Doktora Tezi. Frrat Üniversitesi Eğitim Bilimleri Enstitüsü, Elazı̆̆.

Yokuş, İ. (2006). Erkek egemen işlerde çalışanların örgütsel destek algıları ile örgütsel bağlılıkları arasındaki ilişki. Yayımlanmamış yüksek lisans tezi. Hacettepe Üniversitesi, Ankara.

Yoon, J., \& Lim, J. C. (1999). Organizational support in the workplace: The case of Korean hospital employees. Human Relations, 52, 923-945.

Yu, C., \& Frenkel, S. J. (2013). Explaining task performance and creativity from perceived organizational support theory: Which mechanisms are more important? Journal of Organizational Behavior, 34, 1165-1181.

Zafer, M. (2016). Itfaiye çalışanlarında psikolojik dayanıklılık ve kendini sabotaj düzeylerinin incelenmesi: Istanbul İtfaiyesi örneği. Yayınlanmamış yüksek lisans tezi. Nişantaşı Üniversitesi Sosyal Bilimler Enstitüsü,İstanbul. 